Article

\title{
Experimental Investigation of Thermal and Pressure Performance in Computer Cooling Systems Using Different Types of Nanofluids
}

\author{
Altayyeb Alfaryjat $@$, Lucian Miron, Horatiu Pop *, Valentin Apostol, \\ Mariana-Florentina Stefanescu and Alexandru Dobrovicescu * \\ Faculty of Mechanical Engineering and Mechatronics, University Politehnica of Bucharest, \\ Splaiul Independentei nr. 313, Sector 6, Bucharest 060042, Romania \\ * Correspondence: horatiu.pop@upb.ro (H.P.); adobrovicescu@yahoo.com (A.D.); Tel.: +40-744903488 (H.P.); \\ +40-744371053 (A.D.)
}

Received: 7 June 2019; Accepted: 26 August 2019; Published: 29 August 2019

\begin{abstract}
A modern computer generates a great amount of heat while working. In order to secure appropriate working conditions by extracting the heat, a specific mechanism should be used. This research paper presents the effect of nanofluids on the microchannel heat sink performance of computer cooling systems experimentally. $\mathrm{CeO}_{2}, \mathrm{Al}_{2} \mathrm{O}_{3}$ and $\mathrm{ZrO}_{2}$ nanoparticles suspended in $20 \%$ ethylene glycol and $80 \%$ distilled water are used as working fluids in the experiment. The concentration of the nanoparticles ranges from $0.5 \%$ to $2 \%$, mass flow rate ranges from $0.028 \mathrm{~kg} / \mathrm{s}$ to $0.084 \mathrm{~kg} / \mathrm{s}$, and the ambient temperature ranges from $25^{\circ} \mathrm{C}$ to $40^{\circ} \mathrm{C}$. Regarding the thermal component, parameters such as thermophysical properties of the nanofluids and base fluids, central processing unit (CPU) temperature, heat transfer coefficient, pressure drop, and pumping power have been experimentally investigated. The results show that $\mathrm{CeO}_{2}-\mathrm{EG} / \mathrm{DW}$, at a concentration of $2 \%$ and a mass flow rate of $0.084 \mathrm{~kg} / \mathrm{s}$, has with $8 \%$ a lower temperature than the other nanofluids and with $29 \%$ a higher heat transfer coefficient compared with the base fluid. The $\mathrm{Al}_{2} \mathrm{O}_{3}-\mathrm{EG} / \mathrm{DW}$ shows the lowest pressure drop and pumping power, while the $\mathrm{CeO}_{2}-\mathrm{EG} / \mathrm{DW}$ and $\mathrm{ZrO}_{2}-\mathrm{EG} / \mathrm{DW}$ show the highest. However, a slight increase of pumping power and pressure drop can be accepted, considering the high improvement that the nanofluid brings in computer cooling performance compared to the base fluid.
\end{abstract}

Keywords: computer cooling system; nanofluids; microchannel heat sink

\section{Introduction}

In the last two decades, many electronic devices, such as high-power chips and LEDs, have appeared, and with them, high heat fluxes that need to be removed in order to maintain the electronic junctions at a normal operating temperature. A new way of removing a large amount of heat from small areas is through the use of a microchannel heat sink (MCHS), which was first presented by Tuckerman and Pease [1]. This idea was discovered based on the reverse relation between the characteristic length of the channel and the heat transfer coefficient. These devices are made of highly solid conductive materials, such as aluminium, copper, and silicone, provided with micro-channels for the passage of the cooling fluid. Moreover, a microchannel heat sink offers several cooling advantages, including being small in size and lightweight, with a high heat transfer coefficient and the ability to bring about a decrease in the device's heat gain [2].

The development of compact devices depends entirely on the success of the thermal management technology for progressive electronic devices; such types of devices must have a high performance, low weight, and small size. A solution is offered by the MCHS, which can resolve the problems of heat 
dissipation in current developing applications. The MCHS is a device that can be made to extract heat from the CPU. Therefore, MCHS has received significant attention from researchers in recent years.

Khonsue [3], for example, experimentally investigated the cooling performance of a MCHS made of aluminum. The width, length, and base thickness of the microchannel were 40, 28, and $2 \mathrm{~mm}$. Deionized water was used as a base fluid. It was found that increasing the height of the channels and the speed of the water flow led to an increase in the heat transfer rate. Tran et al. [4] studied experimentally and numerically the pressure drop of the MCHS made from aluminum. The mass flow rates were found to range between 0.2 to $0.4 \mathrm{~g} / \mathrm{s}$, while the inlet water temperature was $25^{\circ} \mathrm{C}$. The results show that when the mass flow rate rises, the pressure drop increases. Ma et al. [5] experimentally investigated the heat transfer and the fluid flow of a 4-port heat sink with a zigzag and rectangular MCHS. The deionized water flow rate was found to range between 28 to $72 \mathrm{~mL} / \mathrm{min}$ with an inlet temperature equal to $25^{\circ} \mathrm{C}$. It was found that at a low flow speed, the zigzag microchannel has a lower pressure drop than the rectangular microchannel, but when the flow increases, the pressure drop increases more in the zigzag microchannel than in the rectangular microchannel. Moreover, the heat transfer of the zigzag microchannel showed better results than the rectangular microchannel.

While the scales of MCHS devices are becoming smaller due to the rapid development of technology, the heat flux generated is seemingly increasing. In the nanotechnology field, recent developments have revealed a new set of heat transfer fluids, named nanofluids, such as those studied by Choi and Eastman [6] at the National Laboratory. Their research distinguished two principal advantages of using nanofluids: (1) they are comprised of milled particles or microparticles with a higher thermal conductivity than fluids; and (2) they have a better constancy.

Many researchers reported in their reviews that adding nanoparticles to the base fluid led to the increase in the thermal conductivity and viscosity of the nanofluids [7,8]. Nandhaumar and Senthilkumar [9] investigated the thermo physical properties of different nanoparticles such as $\mathrm{ZnO}$, $\mathrm{MgO}, \mathrm{TiO}_{2}$ and $\mathrm{Al}_{2} \mathrm{O}_{3}$ by using water and ethylene glycol as a base fluid. The volume fraction ranges between 0.5 to $2.5 \%$. It was reported that, at a concentration of $2.5 \%, \mathrm{MgO}-\mathrm{H}_{2} \mathrm{O}$ has the highest thermal conductivity, with $7.4 \%$ enhancement over other nanofluids. Jeong et al. [10] investigated experimentally the thermal conductivity and viscosity of the $\mathrm{ZnO}$ nanofluid with a volume faction varying from 0.05 to $5 \%$. Two different nanoparticle diameters of zinc oxide were used. The results show that the thermal conductivity improves up to $18 \%$ at the volume fraction of $5 \%$. Lee et al. [11] studied the fluid thermal conductivity of $\mathrm{CuO}$ with nanoparticle diameters of $18.6 \mathrm{~nm}$ and $23.6 \mathrm{~nm}$ and $\mathrm{Al}_{2} \mathrm{O}_{3}$ with diameters of $24.4 \mathrm{~nm}$ and $38.4 \mathrm{~nm}$ suspended in two base fluids such as ethylene Glycol (EG) and water. They studied four different nanofluids; $\mathrm{CuO}$ in $\mathrm{EG}, \mathrm{CuO}$ in water, $\mathrm{Al}_{2} \mathrm{O}_{3}$ in water, and $\mathrm{Al}_{2} \mathrm{O}_{3}$ in $\mathrm{EG}$. They reported that the $\mathrm{CuO} / \mathrm{EG}$ mixture showed $20 \%$ enhancement at $4 \mathrm{wt}$. $\%$ compared with other nanofluids.

Nanoparticle size is another factor which affects the viscosity and the thermal conductivity of the nanofluids. Alawi et al. [12] investigated experimentally and numerically the effect of nanoparticles size on the thermal properties of the nanofluids. They used different nanoparticles such as $\mathrm{ZnO}_{1} \mathrm{SiO}_{2}$, $\mathrm{CuO}$ and $\mathrm{Al}_{2} \mathrm{O}_{3}$ with diameter ranging from $20 \mathrm{~nm}$ to $100 \mathrm{~nm}$. The results show that by decreasing the nanoparticles size led to the increase in the thermal conductivity of the nanofluids. Namburu et al. [13] investigated the effect of 20,50,100 nm diameter of $\mathrm{SiO}_{2}$ at $6 \%$ concentration using ethylene glycol and distilled water as a working fluid. They reported that the viscosity of the nanofluid increases when the nanoparticles size decreases. Eastman et al. [14] experimentally studied the effect of Cu nanoparticles concentration and diameter on the thermal conductivity of the nanofluids using ethylene glycol as a base fluid. It was noted the thermal conductivity enhanced with $40 \%$ at a concentration of $0.3 \%$ for nanoparticles diameters of $10 \mathrm{~nm}$ while at the concentration of $4 \%$ and for nanoparticles diameters of $23.6 \mathrm{~nm}$ the enhancement is $20 \%$.

Other researchers reported that hybrid nanofluids could be considered as a next generation fluid. Esfe et al. [15] conducted an experiment for the measurement of the thermal conductivity of $\mathrm{Cu} / \mathrm{TiO} 2$ suspended in $60 \%$ water and $40 \%$ EG. The nanofluid concentration varied from 0.1 to $2 \%$ and the 
nanoparticle diameter ranged between 40 and $70 \mathrm{~nm}$. It was reported that, at temperature $30{ }^{\circ} \mathrm{C}$, the thermal conductivity increased by $18.2 \%$ when the concentration increases to $2 \%$. Hamid et al. [16] experimentally investigated five mixture ratios of $\mathrm{TiO}_{2}: \mathrm{SiO}_{2}(20: 80,40: 60,50: 50,60: 40$, and 80:20) nanoparticles which were suspended at a concentration of $1.0 \%$ in a solution of $60 \%$ pure water and $40 \%$ EG. The results indicated that all nanofluids show higher viscosity and thermal conductivity than the base fluid $(\mathrm{EG} / \mathrm{W})$. The mixture 20:80 $\left(\mathrm{TiO}_{2}: \mathrm{SiO}_{2}\right)$ nanofluid shows the highest thermal conductivity compared to the other compositions, while for the ratio 50:50 $\left(\mathrm{TiO}_{2}: \mathrm{SiO}_{2}\right)$ the nanofluid shows the highest viscosity. Siddiqui et al. [17] investigated the thermal properties of $\mathrm{Cu} / \mathrm{Al}_{2} \mathrm{O}_{3}$ hybrid nanofluid with ratios 30:70, 50:50 and 70:30. The results show that the hybrid nanofluid with the ratio 50:50 has the best stability and the highest thermal conductivity among the other ratios. Many other researchers investigated the thermal properties of hybrid nanofluids by mixing different nanoparticles [18-20].

Mixing pure water with ethylene glycol was always commercially recommended as a heat transfer fluid for cooling or heating [21-24]. Namburu et al. [25] in 2007 have first reported results on the viscosity of a $40 \%$ of pure water and $60 \%$ of EG base fluid with $\mathrm{CuO}$ nanoparticles. Vajjha and Das [26] experimentally studied the effect of temperature on the thermal conductivity of $\mathrm{CuO}, \mathrm{Al}_{2} \mathrm{O}_{3}$ and $\mathrm{ZnO}$ mixed with $60 \%$ ethylene glycol and $40 \%$ pure water. The test has been done for nanoparticle concentrations ranging from $0 \%$ to $10 \%$ and with temperature ranging from $298 \mathrm{~K}$ to $363 \mathrm{~K}$. It was reported that the thermal conductivity of $\mathrm{Al}_{2} \mathrm{O}_{3}$ mixed with a base fluid of $60: 40 \mathrm{EG} / \mathrm{DW}$ increased with $21 \%$ when the concentration increased to $6 \%$. At a concentration of $10 \%$ the thermal conductivity of the nanofluid increased to $69 \%$ at temperature $365 \mathrm{~K}$ compared with pure water. Reddy and Rao [27] experimentally studied the thermal conductivity of $\mathrm{TiO}_{2}$ with a concentration varying from $0.2 \%$ to $1 \%$ and for nanoparticles a diameter of $21 \mathrm{~nm}$. The nanoparticles were suspended in two different base fluids DW/EG (40\%:60\% and 50\%:50\%). Their results indicated that the thermal conductivity, for 1\% concentration in base pure water, enhanced by $6 \%$ at temperature $30{ }^{\circ} \mathrm{C}$. At the same concentration and temperature, the nanofluid thermal conductivity in base fluid EG/W (40\%/60\%) increased by $4.38 \%$, while its increase is of $10.42 \%$ in a base fluid 50\%/50\% EG/W. Li and Zou [28] conducted an experiment to measure the thermophysical properties of $\mathrm{SiC}$ suspended in water/EG (60:40). HAAKE MARS III rheometer and KD2-Pro thermal analyzer were used to measure the viscosity and thermal conductivity of the nanofluid concentration varying from 0 to $1 \%$. Their experimental results showed that, for a $1 \%$ nanofluid concentration, the thermal conductivity increased by $33.8 \%$ compared to the case of the base fluid, while the viscosity increased by $22.4 \%$. Sundar et al. [29] studied the viscosity and the thermal conductivity of $\mathrm{Al}_{2} \mathrm{O}_{3}$ mixed with $20: 80 \%, 40: 60 \%$ and $60: 40 \%$ of ethylene glycol and D water. The volume fraction is varying between 0.3 to $1.5 \%$. It was reported that increase in the volume fraction concentration increased the thermal conductivity and the viscosity of nanofluid. The thermal conductivity enhanced with $32.26 \%$ for the fluid $20: 80 \mathrm{EG} / \mathrm{W}$ in $1.5 \%$ volume concentrations and temperature $60^{\circ} \mathrm{C}$. The viscosity of 20:80 EG/W nanofluid appeared 1.29 times enhanced than for the other nanofluids at a volume concentration of $1.5 \%$ and temperature $0{ }^{\circ} \mathrm{C}$. They also investigated the effect of $\mathrm{Fe}_{3} \mathrm{O}_{4}$ suspended in EG/DW (20:80\%, 40:60\% and 60:40\%) [30]. They found that for $\mathrm{Fe}_{3} \mathrm{O}_{4}$ mixed with base fluid EG/DW (20:80), at temperature $20{ }^{\circ} \mathrm{C}$, the thermal conductivity increased by $21.96 \%$ at the concentration by $2 \%$.

The ultrafine suspended particles change the properties of transport and increase the heat transfer performance of the nanofluids as presented by Ahmed et al. [31]. However, the suspended particles with the usual slurries in millimeters or even micrometers may, at the end, cause several problems. For example, the abrasive action of the particles may clog or erode the pipelines. The fluid flow is accompanied by an increase in the pressure drop and additional rheological and instability problems can occur. As particles tend to settle rapidly, the slurries can provide better thermal conductivity. With the development of nanotechnology and nanoscience, the appearance of nanofluids has a great potential to enhance the means of thermal science, heat transfer and engineering challenges. Nonetheless, as the concept of nanofluids has been recently proposed, there are many unclear questions that need to be resolved [32,33]. 
In the past decade, due to their high thermal properties, the number of investigations related to nanofluids have increased. The interdisciplinary nature of research on nanofluids provides an insight into the opportunities to explore and discover nanotechnology frontiers [34]. The benefits of the use of nanofluids in computer technology are very promising.

Nguyen et al. [35] experimentally investigated the heat transfer performance of a computer cooling system. An $\mathrm{Al}_{2} \mathrm{O}_{3}$-water nanofluid was used as the cooling fluid inside the system. A 23\% enhancement in the heat transfer coefficient of the nanofluid was found as compared with pure water. In addition, the temperature of the water block decreased, and the Nusselt number increased as the particle concentration increased. The heat transfer also increased, and the temperature decreased when the mass flow increased. Chein and Chuang [36] investigated MCHS performance using $\mathrm{CuO}-\mathrm{H}_{2} \mathrm{O}$ with a volume fraction of 0.2 to $0.4 \%$. They concluded that, compared with pure water, the nanofluid absorbed more thermal energy. Increasing the inflow rate showed no enhancement in the heat absorption. Since the nanoparticles of the nanofluid increased the viscosity of the fluid and the wall roughness, this behavior led to a slight increase in the pressure drop. Ho et al. [37] examined experimentally the convective force of the MCHS by using $\mathrm{Al}_{2} \mathrm{O}_{3}-\mathrm{H}_{2} \mathrm{O}$ as a working fluid with a volume fraction factor range from 0 to $2 \%$. They reported that the nanofluid increased the density and thermal conductivity of the base fluid. The heat transfer coefficient showed a 70\% enhancement in the MCHS performance when the nanofluid was used as a working fluid compared to pure water. They also discovered that nanofluids could reduce thermal resistance and the maximum wall temperature, which was a better result than pure water.

Tiwari et al. [38] experimentally investigated the heat transfer performance of the plate heat exchanger using different nanofluids such as $\mathrm{CeO}_{2} / \mathrm{H}_{2} \mathrm{O}, \mathrm{Al}_{2} \mathrm{O}_{3} / \mathrm{H}_{2} \mathrm{O}, \mathrm{TiO}_{2} / \mathrm{H}_{2} \mathrm{O}$ and $\mathrm{SiO}_{2} / \mathrm{H}_{2} \mathrm{O}$ with various concentrations. It was reported that $\mathrm{CeO}_{2} / \mathrm{H}_{2} \mathrm{O}$ nanofluid obtained the highest overall heat transfer coefficient ratio followed by $\mathrm{Al}_{2} \mathrm{O}_{3}, \mathrm{TiO}_{2}$, and finally $\mathrm{SiO}_{2}$. Haghighi et al. [39] experimentally studied the effect of nanofluid such as $\mathrm{Al}_{2} \mathrm{O}_{3}, \mathrm{ZrO}_{2}$ and $\mathrm{TiO}_{2}$ suspended in pure water on microtube performance. It was reported that the alumina and zirconia nanofluids show higher heat transfer coefficients at the same Reynolds number.

An experiment carried out by Rimbault et al. [40] studied the hydraulic and thermal fields of $\mathrm{CuO}-\mathrm{H}_{2} \mathrm{O}$ inside a rectangular MCHS. They found that increasing the mass flow rate and the volume concentrations of nanoparticles led to an increase in the pressure drop of the nanofluid. The high temperature of the fluid led to a decrease in the viscosity of the fluid and afterwards a decrease in the pressure drop. They also found that, at low concentration, there was a slight heat transfer enhancement of $0.24 \%$ and $1.03 \%$, respectively. However, at a concentration of $4.5 \%$, a clear increase of heat transfer was found. Nazari et al. [41] examined the CPU performance by using different volume fractions of $\mathrm{Al}_{2} \mathrm{O}_{3}$ and $\mathrm{CNT}$ as a nanoparticle. $30 \%$ and $50 \%$ of ethylene glycol (EG) mixed with pure water was used as a based fluid. They found that mixing pure water with $30 \%$ of EG had a better cooling performance than pure water. The temperature reduced by about $22 \%$ when using CNT as a working fluid, but with the $\mathrm{Al}_{2} \mathrm{O}_{3}$ nanofluid, it dropped by $20 \%$. The heat transfer enhanced by $6 \%$ and $13 \%$ when using $0.5 \%$ of $\mathrm{Al}_{2} \mathrm{O}_{3}-\mathrm{H}_{2} \mathrm{O}$ and $0.25 \%$ of $\mathrm{CNT}-\mathrm{H}_{2} \mathrm{O}$, respectively.

Sivakumar et al. [42] numerically and experimentally examined the performance of various nanofluids, such as $\mathrm{Al}_{2} \mathrm{O}_{3}-\mathrm{H}_{2} \mathrm{O}, \mathrm{CuO}-\mathrm{H}_{2} \mathrm{O}$, and $\mathrm{CuO}-\mathrm{EG}$, in serpentine-shaped $\mathrm{MCHS}$. The microchannels were made from copper with a hydraulic diameter ranging from 810 to $890 \mu \mathrm{m}$. The results showed that, due to the high density and viscosity, the CuO-EG had the highest transfer coefficient and pressure drop of all the nanofluids. Decreasing the diameter of the microchannels led to an improvement in the heat transfer coefficient and an increase in the pressure drop. Furthermore, Singh and Kumar [43] experimentally examined the fluid flow and heat transfer of wavy rectangular MCHS made by aluminum. To improve cooling performance, different concentrations of $\mathrm{Al}_{2} \mathrm{O}_{3}$ were mixed with water. They showed that increasing the Reynolds number and concentration of nanoparticles decreased the thermal resistance of MCHS and improved the overall heat transfer. A 3\% volume concentration appeared at the highest pressure drop. 
Arslan et al. [44] investigated the performance of a carbon nanotube (CNT) as a coolant in MCHS. They used a $0.01 \%$ weight concentration of carbon nanotube mixed with pure water. They found that, at a very low Reynolds number, the temperature difference of the carbon nanotube was higher than $30 \%$ as compared to pure water. The temperature difference between the CNT nanofluid and water were slightly similar when the flow rate increased. The pressure drop of CNT was close to the water in the case when the Reynolds number was less than 2000. A small addition of CNT to the base fluid led to an increase in the pressure to $1 \%$ at a low Reynolds number. However, increasing the Reynolds number led to a rise in the pressure of $8 \%$. Increasing the Reynolds number was found to increase the pumping power. Thansekhar and Anbumeenakshi [45] studied the performance of aluminum MCHS using two types of nanofluids: $\mathrm{Al}_{2} \mathrm{O}_{3}-\mathrm{H}_{2} \mathrm{O}$ at a concentration of $0.1 \%$ and $\mathrm{SiO}_{2}-\mathrm{H}_{2} \mathrm{O}$ at a concentration of $0.25 \%$. They stated that the heat transfer of $\mathrm{Al}_{2} \mathrm{O}_{3}-\mathrm{H}_{2} \mathrm{O}$ showed a $36.63 \%$ enhancement compared with pure water. Moreover, the nanofluid caused a slight pressure drop compared with pure water. Furthermore, the performances of different concentrations of $\mathrm{TiO}_{2}-\mathrm{H}_{2} \mathrm{O}$ in microchannels were experimentally investigated by Manay and Sahin [46]. The height of the microchannel was $200 \mu \mathrm{m}$ and the Reynolds number varied from 100 to 750 . The volume fraction ranged between $0.25 \%$ and $2.0 \%$. It was observed that the heat transfer enhanced when the volume fraction reached $2.0 \mathrm{vol} . \%$, then the heat dropped after $2.0 \mathrm{vol} . \%$. In addition, they reported that the thermal resistance decreased when the size of the nanoparticles decreased. Increasing the concentration of the solids and the Reynolds number caused an increase in the Nusselt number.

Finally, it is clear to see from the previously outlined literature review that different nanofluids have been studied widely. However, research on the performance of computer cooling systems with $\mathrm{Al}_{2} \mathrm{O}_{3}, \mathrm{ZrO}_{2}$, and $\mathrm{CeO}_{2}$ suspended in $20 \%$ ethylene glycol and $80 \%$ distilled water have been very limited. Furthermore, there is no study that has yet observed the impact of these types of nanofluids on fluid flow and heat transfer in computer cooling systems. This paper will examine the cooling performance of a personal computer system with the addition of nanoparticles with different concentrations in base fluid at different atmospheric temperatures. A real computer setup with an LGA775 CPU socket has been used to find out the effect of the use of nanofluids and base fluid on the cooling system in real practical conditions. Table 1 presents the summary of experimental studies on the microchannel heat sink with nanofluids.

Table 1. Summary of experimental studies on microchannel heat sink (MCHS) with nanofluids.

\begin{tabular}{|c|c|c|c|c|c|}
\hline Author & N.P Type & $\begin{array}{c}\text { N.P Size } \\
(\mathrm{nm})\end{array}$ & $\begin{array}{l}\text { Base } \\
\text { Fluid }\end{array}$ & V.F \% & MCHS Enhancement \\
\hline $\begin{array}{l}\text { Nguyen et al. } \\
\text { [35] }\end{array}$ & $\mathrm{Al}_{2} \mathrm{O}_{3}$ & 47 & Water & 0.69 to 4.5 & $\begin{array}{l}\text { - } 23 \% \text { enhancement in heat transfer } \\
\text { coefficient of nanofluid }\end{array}$ \\
\hline $\begin{array}{l}\text { Chein and } \\
\text { Chuang [36] }\end{array}$ & $\mathrm{CuO}$ & 20 to 80 & Water & 0.2 to 0.4 & $\begin{array}{l}\text { - Nanofluid absorbed more thermal } \\
\text { energy than pure water. } \\
\text { - Increasing in flow rate shows no } \\
\text { enhancement in the heat absorption. }\end{array}$ \\
\hline Ho et al. [37] & $\mathrm{Al}_{2} \mathrm{O}_{3}$ & 33 & Water & 0 to 2 & $\begin{array}{l}\text { - } 70 \% \text { enhancement in heat } \\
\text { transfer coefficient. }\end{array}$ \\
\hline $\begin{array}{c}\text { Korpyś et al. } \\
\text { [38] }\end{array}$ & $\mathrm{CuO}$ & 30 to 50 & Water & $\begin{array}{c}0.0086 \text { to } \\
0.0225\end{array}$ & $\begin{array}{l}\text { - Nanofluid slightly improved the heat } \\
\text { transfer performance }\end{array}$ \\
\hline $\begin{array}{l}\text { Nitiapiruk et al. } \\
\text { [39] }\end{array}$ & $\mathrm{TiO}_{2}$ & - & Water & $0.5,12$ & $\begin{array}{l}\text { - Nusselt number rise between } 13 \% \text { and } \\
20 \% \text { when the volume concentration } \\
\text { increases between } 0 \text { and } 2 \% \text {. }\end{array}$ \\
\hline
\end{tabular}


Table 1. Cont.

\begin{tabular}{|c|c|c|c|c|c|}
\hline Author & N.P Type & $\begin{array}{l}\text { N.P Size } \\
(\mathrm{nm})\end{array}$ & $\begin{array}{l}\text { Base } \\
\text { Fluid }\end{array}$ & V.F \% & MCHS Enhancement \\
\hline $\begin{array}{l}\text { Rimbault et al. } \\
\text { [40] }\end{array}$ & $\mathrm{CuO}$ & 29 & Water & $0.24,1.03,4.5$ & $\begin{array}{l}\text { - At low concentration, slight heat } \\
\text { transfer enhancement with } 0.24 \% \text { and } \\
1.03 \% \text {, although at concentration } 4.5 \% \\
\text { a clear increase of heat transfer } \\
\text { was found }\end{array}$ \\
\hline $\begin{array}{c}\text { Nazari et al. } \\
{[41]}\end{array}$ & $\mathrm{Al}_{2} \mathrm{O}_{3} \mathrm{CNT}$ & 40 & Water EG & $0.1,0.25,0.5$ & $\begin{array}{l}\text { Mixing the pure water with } 30 \% \text { of } \\
\text { ethylene Glycol (EG) has better } \\
\text { cooling performance than pure water } \\
\text { Temperature decreased about } 20 \% \text { by } \\
\text { using Alumina nanofluid and } 22 \% \text { in } \\
\text { the case of carbon nanotube }(\mathrm{CNT}) \text {. }\end{array}$ \\
\hline $\begin{array}{l}\text { Singh and } \\
\text { Kumar [43] }\end{array}$ & $\mathrm{Al}_{2} \mathrm{O}_{3}$ & - & Water & 1 to 3 & $\begin{array}{l}\text { Increasing in concentration of } \\
\text { nanoparticles and Reynolds number } \\
\text { lead to decrease the thermal resistance } \\
\text { of MCHS. }\end{array}$ \\
\hline $\begin{array}{c}\text { Arslan et al. } \\
{[44]}\end{array}$ & $\mathrm{CNT}$ & - & Water & 0.01 & $\begin{array}{l}\text { - At very low Reynolds number, the } \\
\text { temperature difference rang of carbon } \\
\text { nanotube is higher with } 30 \% \text { as } \\
\text { compared to pure water. }\end{array}$ \\
\hline $\begin{array}{c}\text { Manay and } \\
\text { Sahin [46] }\end{array}$ & $\mathrm{TiO}_{2}$ & 25 & Water & $\begin{array}{c}0.25,0.5,1 \\
1.5,2\end{array}$ & $\begin{array}{l}\text { Heat transfer enhanced when the } \\
\text { volume fraction reached to } 2.0 \text { vol. } \% \\
\text { then the heat drop after. } \\
\text { The thermal resistance decreases } \\
\text { when the nanoparticles size decreases. }\end{array}$ \\
\hline
\end{tabular}

\section{Nanofluid Preparation and Characterization}

Aluminum oxide $\left(\mathrm{Al}_{2} \mathrm{O}_{3}\right)$, zirconium dioxide $\left(\mathrm{ZrO}_{2}\right)$, and cerium oxide $\left(\mathrm{CeO}_{2}\right)$ nanoparticles were used for the preparation of a nanofluid, which was purchased from Skyspring Nanopowder and Nanoparticles (SSNANO). The properties of the nanoparticles can be seen in Table 2. The scanning electron microscopy (SEM) and X-Ray Diffraction (XRD) images of spherical-shaped $\mathrm{CeO}_{2}, \mathrm{Al}_{2} \mathrm{O}_{3}$, and $\mathrm{ZrO}_{2}$ nanoparticles are shown in Figure 1, taken directly after being received from the company. The SEM and XRD proved that all the nanoparticles are pure and have a diameter of less than $50 \mathrm{~nm}$.

Table 2. The properties of $\mathrm{Al}_{2} \mathrm{O}_{3}, \mathrm{ZrO}_{2}$, and $\mathrm{CeO}_{2}$ nanoparticles.

\begin{tabular}{cccccc}
\hline Nanoparticle & Purity & Diameter & Density & Shape & $\begin{array}{c}\text { Used Nanoparticles } \\
\text { Concentrations (\%) }\end{array}$ \\
\hline $\mathrm{CeO}_{2}$ & $99.9 \%$ & $<50 \mathrm{~nm}$ & $7.22 \mathrm{~g} / \mathrm{cm}^{3}$ & spherical & $0.5,1,2$ \\
$\mathrm{Al}_{2} \mathrm{O}_{3}$ & $99.9 \%$ & $<50 \mathrm{~nm}$ & $3.97 \mathrm{~g} / \mathrm{cm}^{3}$ & Nearly spherical & $0.5,1,2$ \\
$\mathrm{ZrO}_{2}$ & $99.9 \%$ & $<50 \mathrm{~nm}$ & $5.6 \mathrm{~g} / \mathrm{cm}^{3}$ & Nearly spherical & $0.5,1,2$ \\
\hline
\end{tabular}



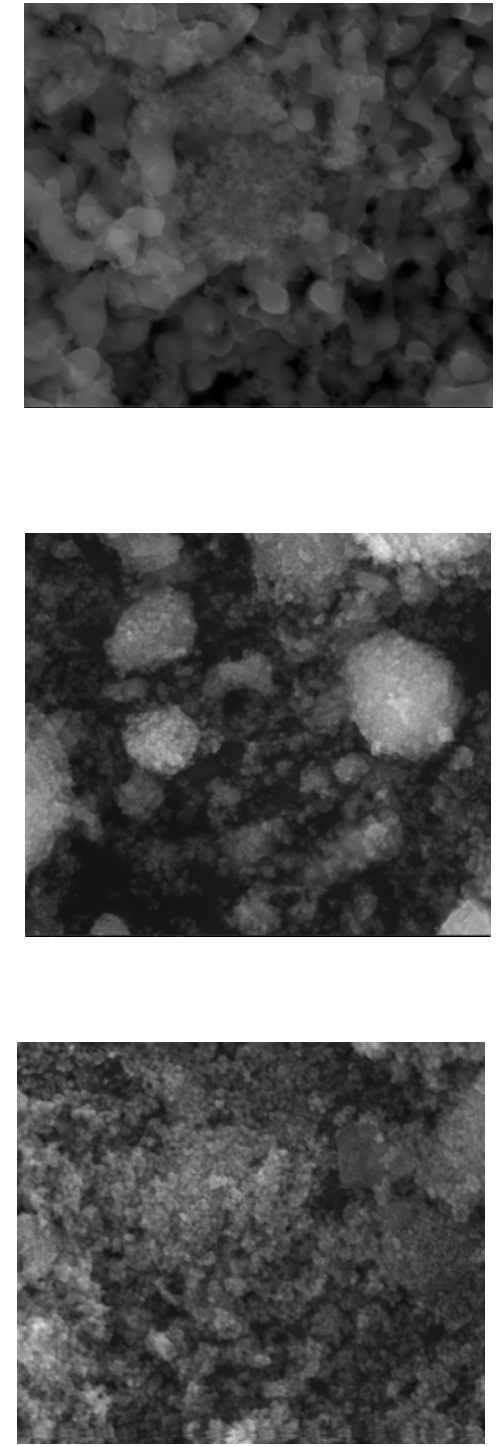

counts

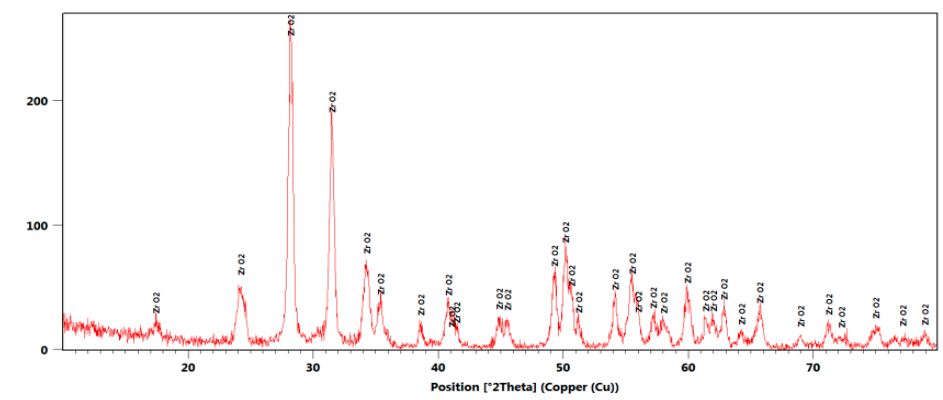

(c)

Figure 1. SEM and $X R D$ of (a) $\mathrm{Al}_{2} \mathrm{O}_{3}$, (b) $\mathrm{CeO}_{2}$, (c) $\mathrm{ZrO}_{2}$ (Left figures show the SEM images and right figures show the XRD images with theta the reflection angle).

To prepare the nanofluids, a two-step method was used [24,28]. An electronic balance (AND-EJ610) was used to quantify the concentration of the nanoparticles with $0.5 \%, 1 \%$, and $2 \%$, respectively. The nanoparticles were suspended in $20 \%$ ethylene glycol and $80 \%$ distilled water using a heating magnetic stirrer. The beaker, which contained $600 \mathrm{~mL}$ of nanofluid, was placed on the magnetic stirrer and stirred for sixty minutes at $1100 \mathrm{rpm}$ and a heat of $55^{\circ} \mathrm{C}$. The ethylene glycol was purchased from Sigma-Aldrich (Bucharest, Romania) and the distilled water was made in the laboratory. In order to decrease the agglomeration and maintain the stability of the nanoparticles in the base fluid, an ultrasonic probe mixer was used for one hour. This ultrasonic probe (Sonics and Materials, Newtown, CT USA) produce pulses with a maximum power of 500 Watts and $20 \mathrm{kHz}$ frequency. Surfactants may reduce the thermal properties of the nanofluids; thus, no surfactants were added. In this work, the observation method was used, since it has been confirmed in previous works [47,48]. The $\mathrm{CeO}_{2}, \mathrm{Al}_{2} \mathrm{O}_{3}$, and $\mathrm{ZrO}_{2}$ nanofluids with concentrations of $0.5 \%, 1 \%$, and $2 \%$, respectively, showed stability for two weeks. 


\section{Thermophysical Properties}

The transient hot-wire method is an operation mechanism applied to find out the thermal conductivity of nanofluids. In order to measure the thermal conductivity of the $\mathrm{CeO}_{2}-\mathrm{EG} / \mathrm{DW}$, $\mathrm{Al}_{2} \mathrm{O}_{3}$-EG/DW, and $\mathrm{ZrO}_{2}$-EG/DW nanofluids, a KD2 Pro thermal analyzer (Decagon Devices Inc., Pullman, WA, USA) was used with an accuracy of $\mp 5 \%$. At a temperature of $25{ }^{\circ} \mathrm{C}$, the thermal conductivity measurements were taken. At the same temperature, the viscosities of the nanofluids with a concentration varying from $0 \%$ to $2 \%$ were recorded using a Brookfield viscometer (DV-I prime) device. Moreover, the base fluid EG/DW (20:80) is considered to play a significant role in the density of the nanofluid. The size and the shape of the nanoparticles were ignored, since they have no effect on the density. A pycnometer was used to find out the density of the nanofluids. The measurements (thermal conductivity, density, and viscosity) were started with the base fluid EG/DW (20:80) for data verification and the results were compared with the DOW guide (Dow Chemical Company, Midland, MI, USA) [49] to validate the accuracy of the device and measurement procedure. All the measurements were recorded three times and the averages of these readings were used for analysis. However, the specific heat can be easily found based on Equation (1) [50].

$$
C_{n f}=\frac{(1-\varphi)(\rho C)_{b f}+\varphi(\rho C)_{n p}}{\rho_{n f}}
$$

where $C_{n f}, C_{b f}, C_{n p}$ represent the specific heat of the nanofluid, base fluid, and nanoparticles, respectively. $\rho_{n f}, \rho_{b f}, \rho_{n p}$ represent the density of the nanofluid, base fluid, and nanoparticles, respectively. $\varphi$ represent the nanoparticles concentration in the nanofluid.

Table 3 shows the thermophysical properties of $\mathrm{Al}_{2} \mathrm{O}_{3}, \mathrm{CeO}_{2}$, and $\mathrm{ZrO}_{2}$ nanoparticles suspended in EG/DW (20:80) with concentration $0.5 \%, 1 \%$, and $2 \%$ at $25^{\circ} \mathrm{C}$.

Table 3. Thermo-physical properties of the nanofluids at temperature $25^{\circ} \mathrm{C}$.

\begin{tabular}{cccccc}
\hline Working Fluid & Concentration $\%$ & $\mathbf{K}(\mathbf{W} / \mathbf{m} \cdot \mathbf{K})$ & $\left.\mathrm{C}_{\mathbf{p}}(\mathbf{J} / \mathbf{( k g} \cdot \mathbf{K})\right)$ & $\rho\left(\mathbf{k g} / \mathbf{m}^{3}\right)$ & $\mu\left(\mathbf{N s} / \mathbf{m}^{2}\right)$ \\
\hline Base fluid & 0 & 0.498 & 3828 & 1029 & 0.00147 \\
\hline \multirow{2}{*}{$\mathrm{CeO}_{2}$ EG/DW } & 0.5 & 0.527 & 3713 & 1057 & 0.00159 \\
& 1 & 0.535 & 3605 & 1089 & 0.00173 \\
& 2 & 0.547 & 3406 & 1152 & 0.00188 \\
$\mathrm{Al}_{2} \mathrm{O}_{3}$ EG/DW & 0.5 & 0.525 & 3771 & 1040 & 0.00153 \\
& 1 & 0.532 & 3717 & 1058 & 0.00166 \\
& 2 & 0.545 & 3612 & 1086 & 0.00178 \\
$\mathrm{ZrO}_{2}$ EG/DW & 0.5 & 0.503 & 3737 & 1047 & 0.00158 \\
& 1 & 0.509 & 3650 & 1076 & 0.00171 \\
& 2 & 0.518 & 3487 & 1119 & 0.00187 \\
\hline
\end{tabular}

\section{Experimental Setup}

An experimental setup was created to investigate the thermal and heat transfer performances of the computer cooling system on the CPU using nanofluids and base fluid. The experimental setup with all components is shown in Figure 2a, while the schematic diagram of the complete experimental setup is shown in Figure 2b. The setup consists of a computer cooling system (water block, radiator, fans, pump, reservoir, tubes, fitting), motherboard (CPU, power supply, external hard), and sensors (pressure sensor, temperature sensors, flow meter sensor). 


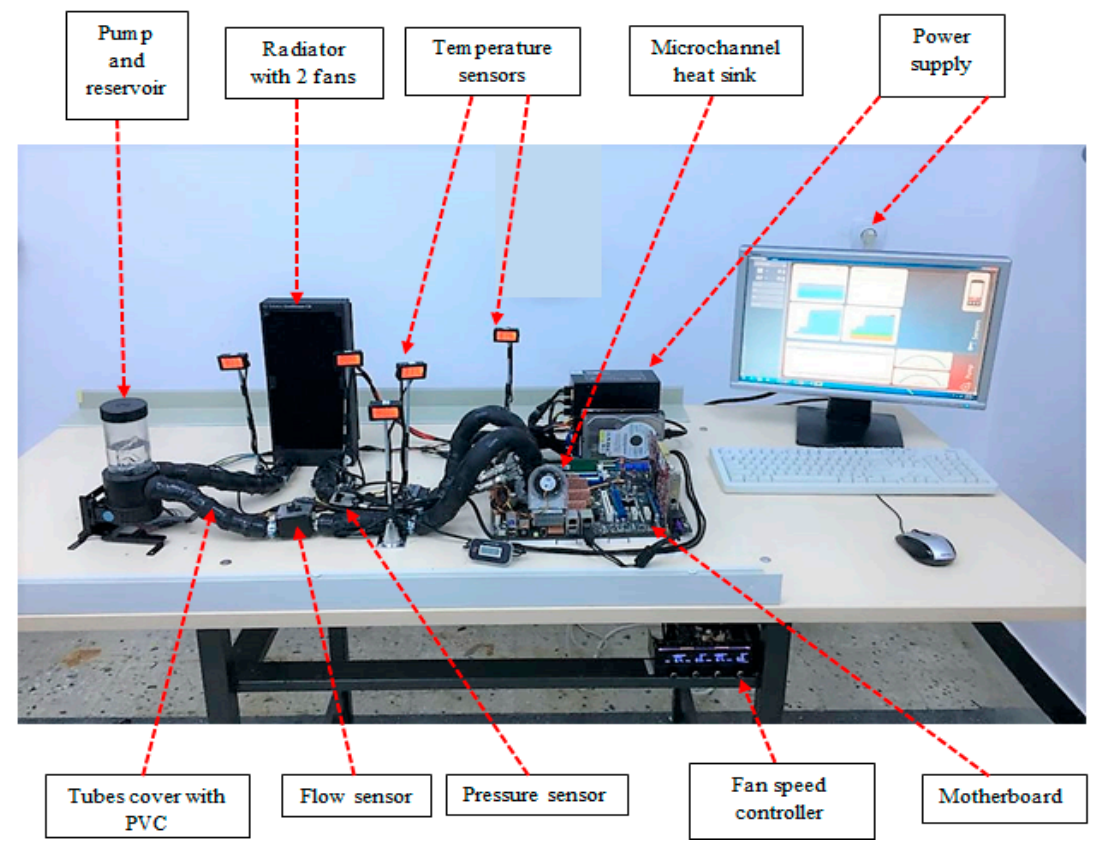

(a)

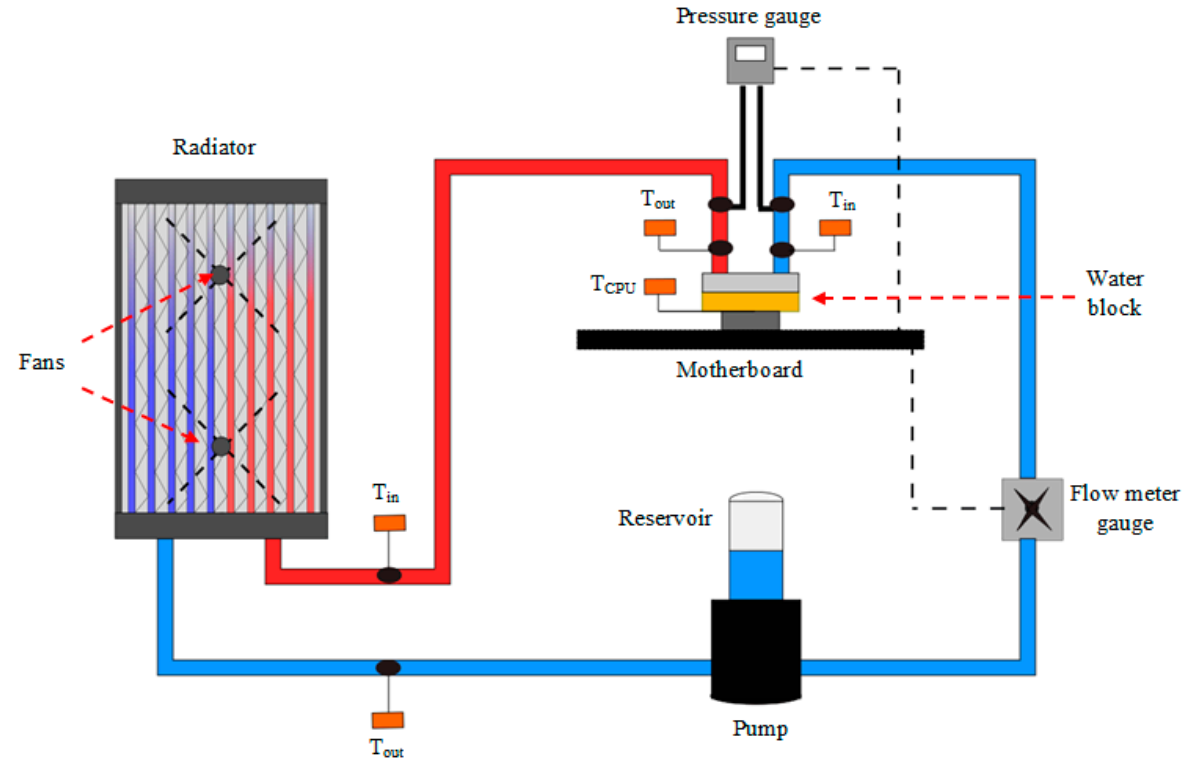

(b)

Figure 2. (a) The experimental setup, (b) The schematic diagram of the water-cooling system.

The computer cooling system type EK-KIT P360 (EKWB Company, Komenda, Slovenia) was used in this experiment. It consists of a water block, radiator, fans, pump, reservoir, tubes, and fitting. The dimensions of the water block are $(57 \times 57 \times 22) \mathrm{mm}^{3}$ and it is made of two parts. The cover is made from acrylic and the base is made from copper. The fluid inlet and outlet of the water block are fixed on the top of the cover. The copper base (microchannel heat sink) of the water block consists of 52 channels with a $0.3 \mathrm{~mm}$ width, $2 \mathrm{~mm}$ height, and $33 \mathrm{~mm}$ length, as seen in Figure 3a. $1500 \mathrm{~L}$ per hour is the maximum flow rate of the pump (D5 pump) with an integrated reservoir. It operates silently and produces less noise, since it has a special rubber shock absorber. Two fans with a maximum speed of $1200 \mathrm{rpm}$ were fixed on the radiator. The radiator offers a large surface heat transfer, since the fins and tubes are made from copper with a $290 \mathrm{~mL}$ liquid capacity. To connect the main parts of the experiment, special tubes and fittings were used. 


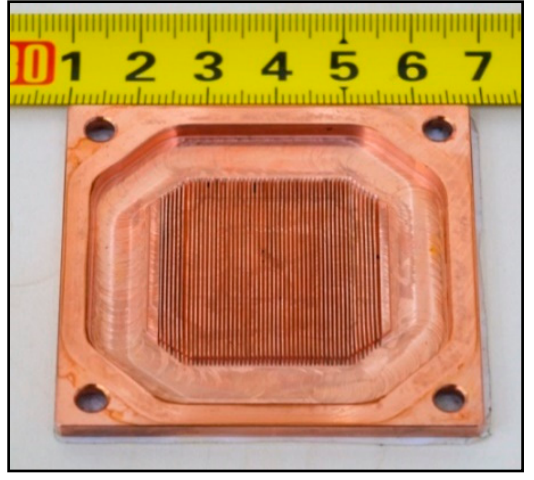

(a)

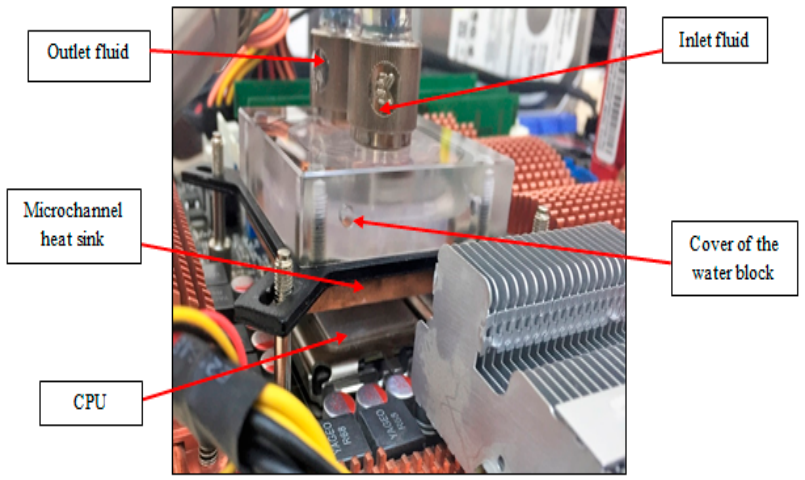

(b)

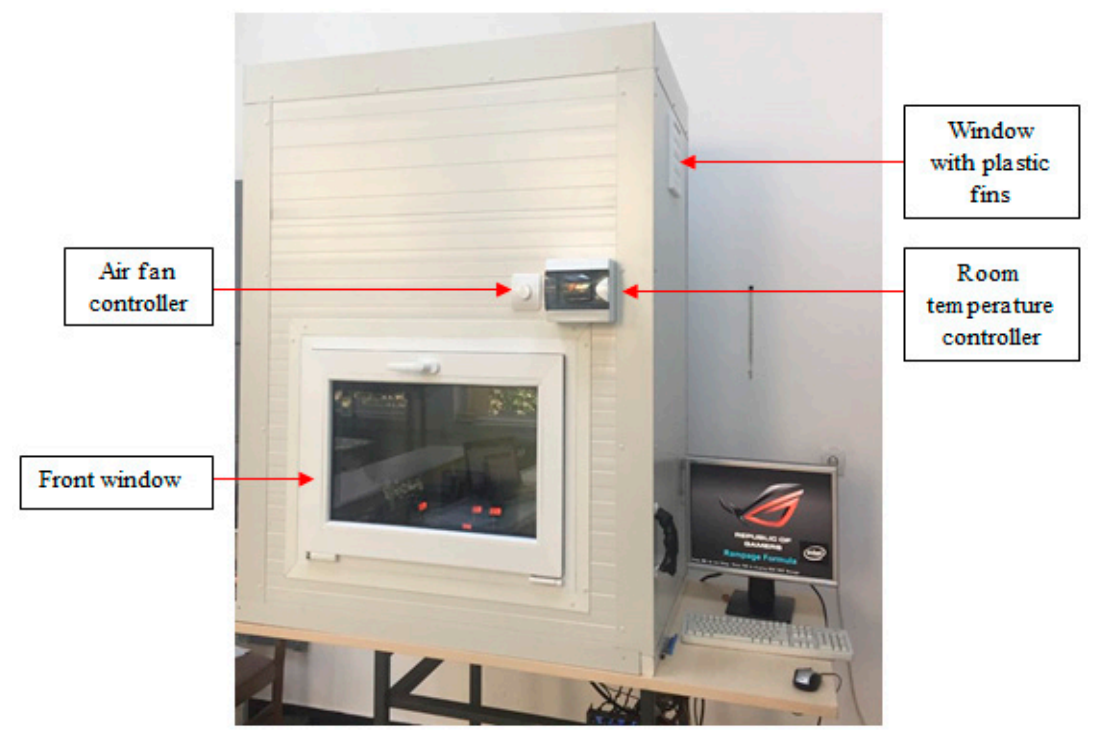

(c)

Figure 3. (a) Microchannel heat sink, (b) water block fixed above the CPU, (c) insulated room.

In the experiment, an ASUS X48 motherboard was used, since it offers the best hardware engineering, the most innovating ideas, and the fastest performance [51]. It also ensures higher overclock ability, so the frequency and voltage can be raised to produce more heat under operation. Through a land grid array (LGA) surface mount socket, the central processor unit (CPU) connects to the motherboard. The name of the socket is LGA775 as it contains 775 contacts arrayed with two cores [52]. The CPU top surface was covered with the thermal interface $(8.5 \mathrm{~W} /(\mathrm{m} \cdot \mathrm{K}))$ to ensure equal distribution of the temperature on the surface, since it provides an effective heat transfer. In addition, a flat temperature sensor was fixed above the CPU interface to record the base heat sinks temperature of the water block. The water block was fixed above the CPU with four screws, as shown in Figure $3 b$. A fiberglass insulation room with a fan heater was built around the experiment to ensure that the ambient temperature was stable or could be increased. A glass window was placed on the front of the room to enable the temperature reading, as can be seen in Figure 3c.

The pump pushes the coolant to the water block with different mass flow rates, such as $0.028 \mathrm{~kg} / \mathrm{s}$, $0.056 \mathrm{~kg} / \mathrm{s}$, and $0.084 \mathrm{~kg} / \mathrm{s}$, respectively. The speed of the pump is controlled by a special controller made in the laboratory. The mass flow of the working fluid was recorded based on Aqua software. To examine the convection heat transfer and pressure drop, LCD temperature sensors and one pressure drop sensor are placed in the inlet and outlet of the water block. LCD temperature sensors have ability to measure the temperature between $-40{ }^{\circ} \mathrm{C}$ and $70{ }^{\circ} \mathrm{C}$. In this experiment, four temperature sensors with the $\mathrm{T}$ fitting $\left(\mathrm{G} 1 / 4^{\prime}\right)$ were fixed on the inlet of the water block and radiator. Another 
type of sensor is a flat sensor which is fixed between the CPU and water block. The sensitivity of the sensors is $0.1^{\circ} \mathrm{C}$. Both sensors have been calibrated prior to being used in this work. LCD temperature sensor are made by XSPS Company in Germany. All the experimental temperature readings have been recorded directly from the digital screen. The coolant leaves the water block towards the massive radiator in order to reject the heat and then the process was repeated. Rubber foam insulation was used to cover all the tubes to prevent any thermal contact with the atmosphere. The setup was run without any overclock from the CPU for twenty-four hours to ensure that the computer cooling system had a leak-proof circuit. After that, the heat flux was applied to the copper block by making stress with high overclocking over the CPU. The experimental study was repeated many times on different days to ensure the repeatability of the experiment. After the experiments, it was noted that that few nanoparticles sticking to the surface of the MCHS. However, the MCHS surface looked clean and without any corrosion after the measurements.

\section{Data Processing}

The most indicative parameter, at this work, is the heat transfer coefficient of the working fluid to the water block. It has been studied based on Newton's cooling law [53];

$$
q=h \cdot A \cdot \Delta T_{m}
$$

where $q$ represents the heat generation rate in the processor, $h$ represents the coefficient of the heat transfer, $A$ represents the heat transfer area, and $\Delta T_{m}$ represent the Log mean temperature difference between the MCHS walls and the working fluid which can be described below [53].

$$
\Delta T_{m}=\frac{T_{\text {out }}-T_{\text {in }}}{\ln \frac{T_{\text {hsbt }}-T_{\text {in }}}{T_{\text {hsbt }}-T_{\text {out }}}}
$$

In which $T_{\text {out }}$ and $T_{\text {in }}$ are the fluid temperatures at the outlet and inlet of the water block, and $T_{\text {hsbt }}$ represents the heat sink base temperature that is considered constant.

Passing the working fluid through the water block leads to an increase in the temperature since the heat absorbed by it [53];

$$
q=\dot{m} \cdot C_{b f, n f}\left(T_{\text {out }}-T_{\text {in }}\right)
$$

where $\dot{m}$ is the mass flow rate $(\mathrm{kg} / \mathrm{s}), C_{b f, n f}$ is the specific heat of base fluid and nanofluid $(\mathrm{J} /(\mathrm{kg} \cdot \mathrm{K}))$.

By equating Equations (2) and (4), the convective heat transfer coefficient can be written as [53]:

$$
h=\frac{\dot{m} \cdot C_{b f, n f}\left(T_{\text {out }}-T_{\text {in }}\right)}{A \frac{T_{\text {out }}-T_{\text {in }}}{\ln \frac{T_{\text {hsb }}-T_{\text {in }}}{T_{h s b t}-T_{\text {out }}}}}
$$

The pumping power has been calculated based on the below Equation [54];

$$
P p=\frac{\dot{m}}{\rho_{b f, n f}} \Delta P
$$

where $\dot{m}$ is the mass flow rate, $\rho_{b f, n f}$ is the density of the base fluid and nanofluid, $\Delta P$ is the absolute value of the pressure drop.

\section{Results}

\subsection{Heat Sink Base Temperature}

Minimizing the base temperature of the heat sink and the CPU temperature is the main objective of the computer cooling system. While a high heat flux was generated from the processor by increasing 
the load, the base temperature of the heat sink was measured. The heat sink base temperature was measured between the heated source and the water block which was used to evaluate the performance of the cooling system. A flat temperature sensor was placed between the base of the heat sink and the CPU. Figure $4 \mathrm{a}-\mathrm{c}$ shows the heat sink base temperature versus the concentration of the $\mathrm{Al}_{2} \mathrm{O}_{3}-\mathrm{EG} / \mathrm{DW}, \mathrm{CeO}_{2}-\mathrm{EG} / \mathrm{DW}$, and $\mathrm{ZrO}_{2}-\mathrm{EG} / \mathrm{DW}$ nanoparticles varying from $0 \%$ to $2 \%$. During the test, three different mass flow rates of the nanofluids and base fluid were selected, such as $0.028 \mathrm{~kg} / \mathrm{s}$, $0.056 \mathrm{~kg} / \mathrm{s}$, and $0.084 \mathrm{~kg} / \mathrm{s}$. The ambient temperature was fixed at $25^{\circ} \mathrm{C}$. Moreover, the heat sink base temperatures related to the base fluid at different mass flow rates were shown as $0 \%$ concentration.

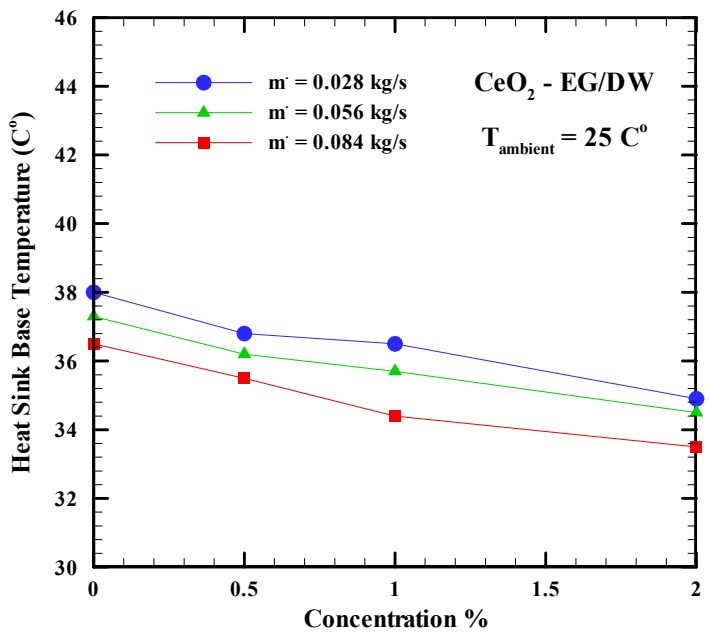

(a)

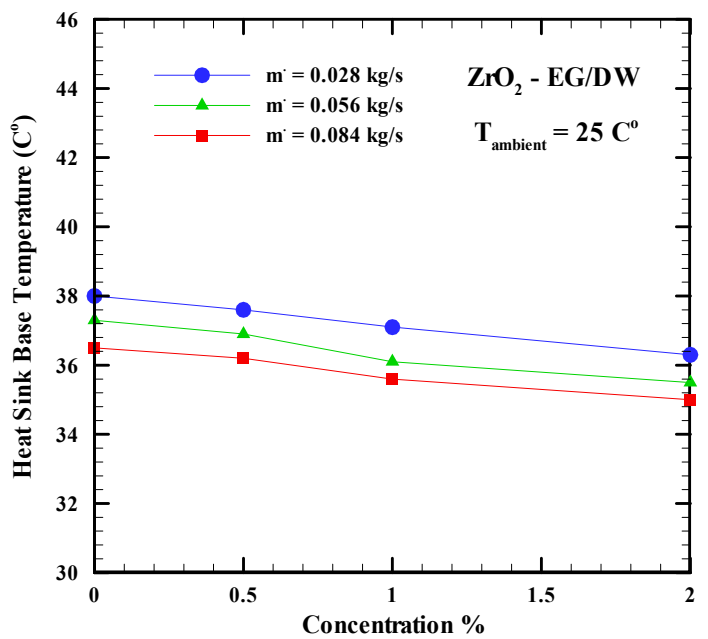

(c)

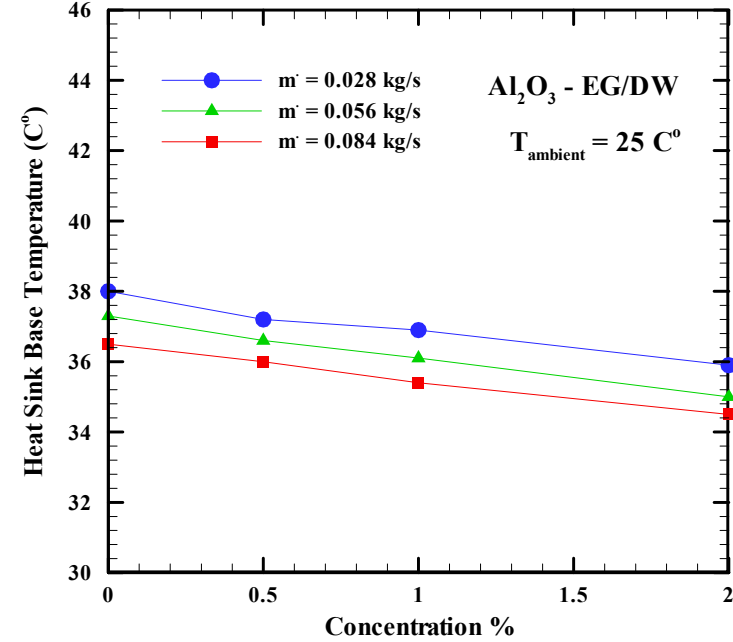

(b)

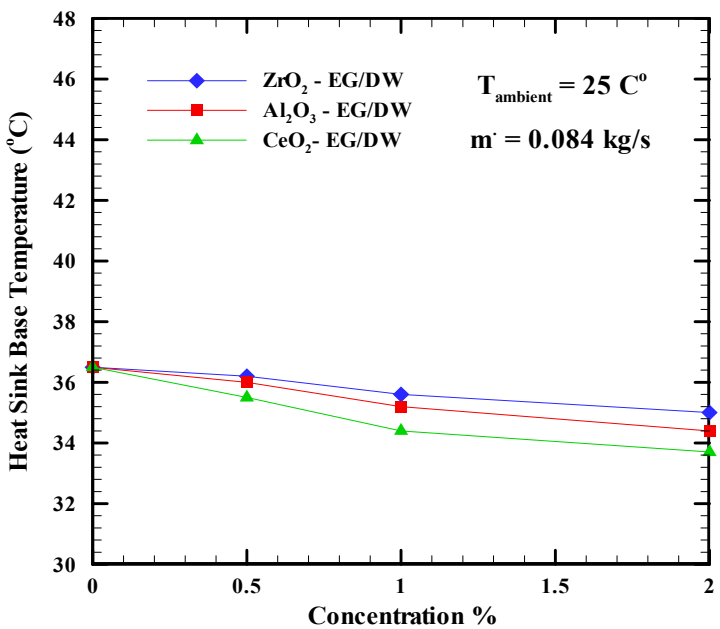

(d)

Figure 4. Heat sink base temperature versus nanoparticles concentrations at different mass flow rates for nanofluids (a) $\mathrm{CeO}_{2}$-EG/DW, (b) $\mathrm{Al}_{2} \mathrm{O}_{3}-\mathrm{EG} / \mathrm{DW}$, (c) $\mathrm{ZrO}_{2}$-EG/DW, (d) different nanofluids.

Figure $4 \mathrm{a}-\mathrm{c}$ proved that adding any nanoparticles to the working fluid in the computer cooling system and increasing the mass flow rate led to larger heat removal from the heated block and kept the interface temperature minimized. This fact was noticed for all three nanoparticles used in this research. Figure $4 \mathrm{a}$ shows the effects of $\mathrm{CeO}_{2}-\mathrm{EG} / \mathrm{DW}$ with different concentrations, such as $0 \%, 0.5 \%$, $1 \%$, and $2 \%$ on the heat sink base temperature. It can clearly be seen that increasing the mass flow rate to $0.084 \mathrm{~kg} / \mathrm{s}$ and the concentration of the nanoparticles to $2 \%$ may drop the heat sink base temperature from $36.5^{\circ} \mathrm{C}$ to $33.7^{\circ} \mathrm{C}$. Using $\mathrm{Al}_{2} \mathrm{O}_{3}-\mathrm{EG} / \mathrm{DW}$ and $\mathrm{ZrO}_{2}-\mathrm{EG} / \mathrm{DW}$ as a working fluid with the same 
mass flow rate and concentration can drop the temperature of the heat sink from $36.5^{\circ} \mathrm{C}$ to $34.4^{\circ} \mathrm{C}$ and from $36.5^{\circ} \mathrm{C}$ to $35^{\circ} \mathrm{C}$, respectively, as shown in Figure $4 \mathrm{~b}, \mathrm{c}$. At an ambient temperature of $25^{\circ} \mathrm{C}$, as shown in Figure $4 \mathrm{~d}$, the use of $\mathrm{CeO}_{2}-\mathrm{EG} / \mathrm{DW}$ with a concentration of $2 \%$, as a working fluid in the computer cooling system, decreased the base temperature of the heat sink more than in the case of the other nanofluids; the decrease in temperature is with $8.3 \%$ larger compared with the base fluid. $\mathrm{Al}_{2} \mathrm{O}_{3}$-EG/DW with $2 \%$ concentration and an ambient temperature of $25^{\circ} \mathrm{C}$ showed a $6.1 \%$ decrease in temperature, while $\mathrm{ZrO}_{2}-\mathrm{EG} / \mathrm{DW}$ showed a $4.2 \%$ decrease. Both results are compared with the base fluid at $0 \%$. This happens because the high viscosity of the $\mathrm{CeO}_{2}-\mathrm{EG} / \mathrm{DW}$ at a $2 \%$ concentration causes a hydraulic thickening and, in turn, the thermal boundary layer thickens. Consequently, CeO2-EG/DW shows the least heat sink temperature since it has the highest viscosity and thermal conductivity compared with other nanofluids.

The effect of the ambient temperature varied from $25^{\circ} \mathrm{C}$ to $40{ }^{\circ} \mathrm{C}$ on the heat sink base temperature and fluid temperature using nanofluids, such as $\mathrm{CeO}_{2}-\mathrm{EG} / \mathrm{DW}, \mathrm{Al}_{2} \mathrm{O}_{3}-\mathrm{EG} / \mathrm{DW}$, and $\mathrm{ZrO}_{2}-\mathrm{EG} / \mathrm{DW}$ with $2 \%$ concentration and a mass flow rate of $0.085 \mathrm{~kg} / \mathrm{s}$ shown in Figure 5 . It can be clearly seen from the figures that increasing the ambient temperature causes an increase in the base temperature of the heat sink and fluid temperature for the base fluid and nanofluids. This happens because when the ambient temperature increases, the temperature of the processor increases which leads to an increase in the heat flux.

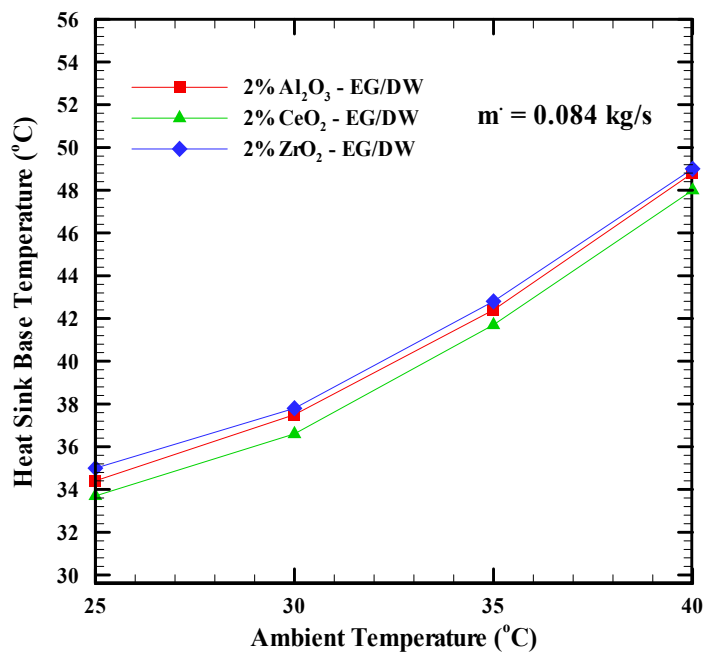

(a)

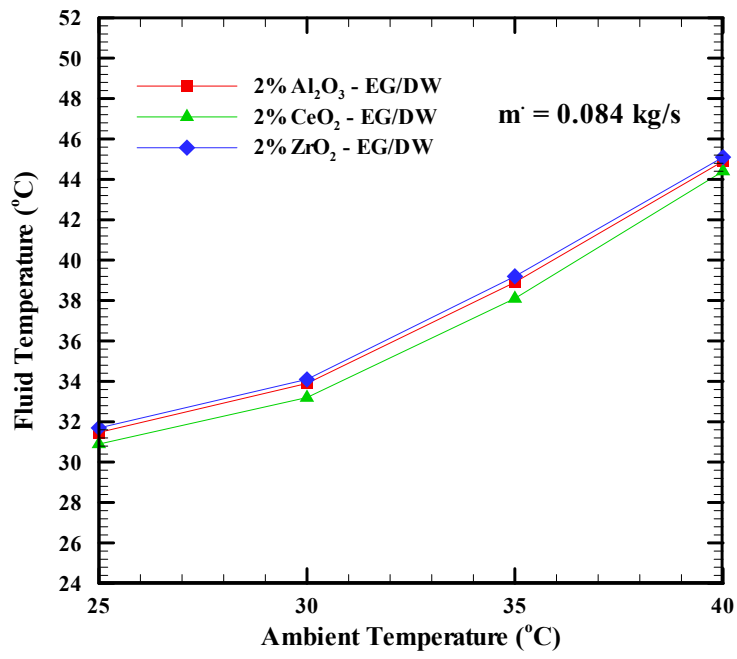

(b)

Figure 5. (a) Heat sink base temperature and (b) Fluid temperature, versus the ambient temperature for different nanofluids.

However, it should be noted that many researchers claim that increasing the mass flow rate by increasing the pump speed can cause unwanted noise. However, in this research, a D5 (PWM) pump was used which silently operates, even at a high speed, since it has a special rubber shock absorber.

\subsection{Heat Transfer Coefficients}

The thermal performance of the nanofluids and how it affects the cooling system and the processor is the main objective of this research. Many researchers report that the thermal performances of nanofluids depend on the convective heat transfer coefficient. The heat transfer coefficient versus the concentration of the $\mathrm{CeO}_{2}-\mathrm{EG} / \mathrm{DW}, \mathrm{Al}_{2} \mathrm{O}_{3}-\mathrm{EG} / \mathrm{DW}, \mathrm{ZrO}_{2}-\mathrm{EG} / \mathrm{DW}$ nanoparticles $(0.5 \%, 1 \%, 2 \%)$ is shown in Figure $6 \mathrm{a}-\mathrm{d}$. The mass flow rates for the base fluid and nanofluids are $0.028 \mathrm{~kg} / \mathrm{s}, 0.056 \mathrm{~kg} / \mathrm{s}$, and $0.084 \mathrm{~kg} / \mathrm{s}$, respectively, with an ambient temperature of $25{ }^{\circ} \mathrm{C}$. A concentration of $0 \%$ is related to the base fluid EG/DW (20:80). Figures show that adding nanoparticles to the base fluid and increasing the mass flow rates lead to an increase in the heat transfer coefficient. This may happen because 
improving the Brownian motion and thermal conductivity of the working fluid may enhance the thermal performances of the nanofluid over the base fluid.

However, increasing the mass flow rate to $0.084 \mathrm{~kg} / \mathrm{s}$ and the concentration to $2 \%$ shows the highest heat transfer coefficient. Figure 6a indicates that the heat transfer coefficient of $\mathrm{CeO}_{2}-\mathrm{EG} / \mathrm{DW}$ increases from $7931 \mathrm{~W} /\left(\mathrm{m}^{2} \cdot \mathrm{K}\right)$ to $11,112 \mathrm{~W} /\left(\mathrm{m}^{2} \cdot \mathrm{K}\right)$ at a mass flow rate of $0.084 \mathrm{~kg} / \mathrm{s}$ when the concentration of the nanoparticles increases from $0 \%$ to $2 \%$. In addition, it increases from $7931 \mathrm{~W} /\left(\mathrm{m}^{2} \cdot \mathrm{K}\right)$ to $10,219 \mathrm{~W} /\left(\mathrm{m}^{2} \cdot \mathrm{K}\right)$ and from $7931 \mathrm{~W} /\left(\mathrm{m}^{2} \cdot \mathrm{K}\right)$ to $9634 \mathrm{~W} /\left(\mathrm{m}^{2} \cdot \mathrm{K}\right)$ when $\mathrm{Al}_{2} \mathrm{O}_{3}$-EG/DW and $\mathrm{ZrO}_{2}$-EG/DW are used as a working fluid, respectively (see Figure $6 \mathrm{~b}, \mathrm{c}$ ). Figure $6 \mathrm{~d}$ clearly indicates that $\mathrm{CeO}_{2}-\mathrm{EG} / \mathrm{DW}$ at a concentration of $2 \%$ and an ambient temperature of $25^{\circ} \mathrm{C}$ shows the highest heat transfer coefficient with a $29 \%$ enhancement compared with the base fluid, followed by $\mathrm{Al}_{2} \mathrm{O}_{3}$-EG/DW and $\mathrm{ZrO}_{2}$-EG/DW with enhancements of $22 \%$ and $17 \%$, respectively. This behavior can be attributed to the high thermal conductivity and viscosity of the $\mathrm{CeO}_{2}$-EG/DW.

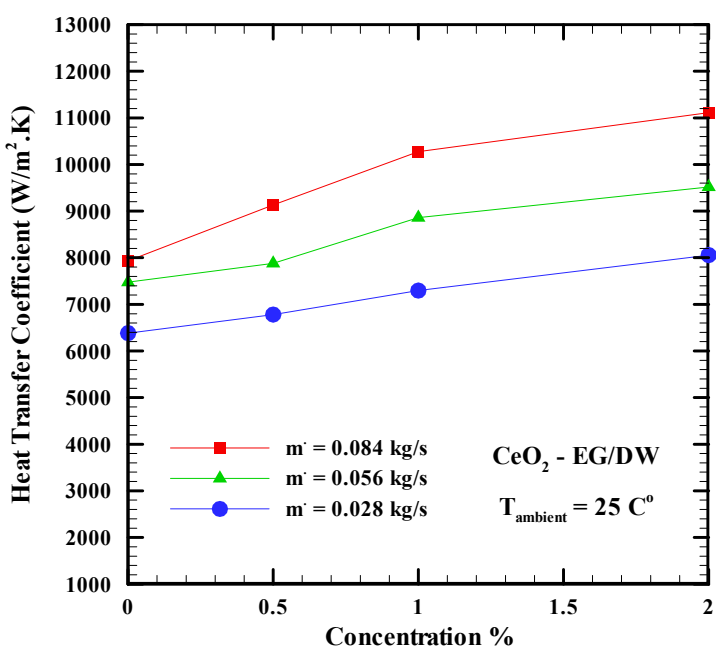

(a)

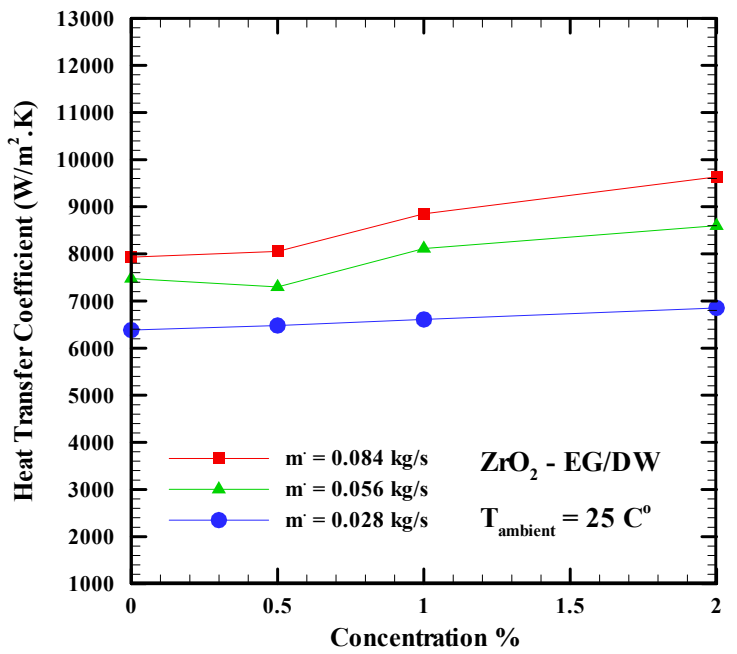

(c)

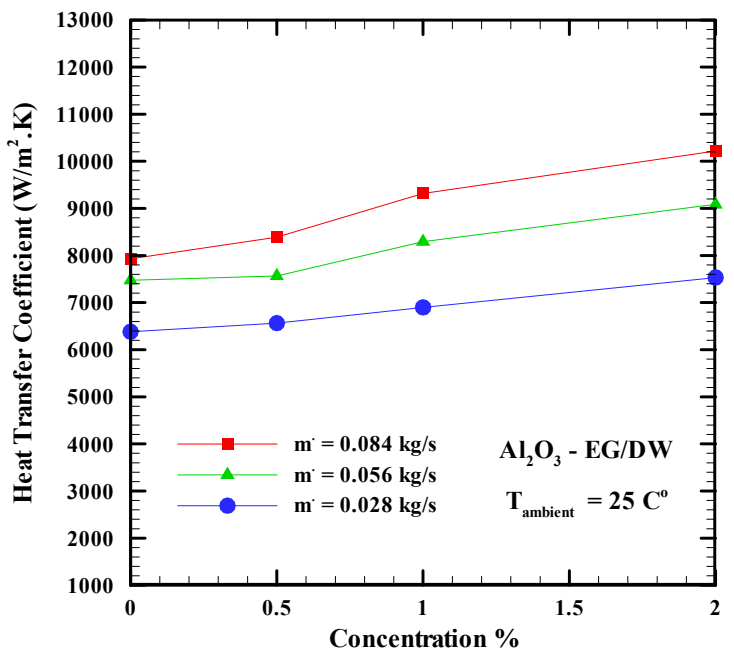

(b)

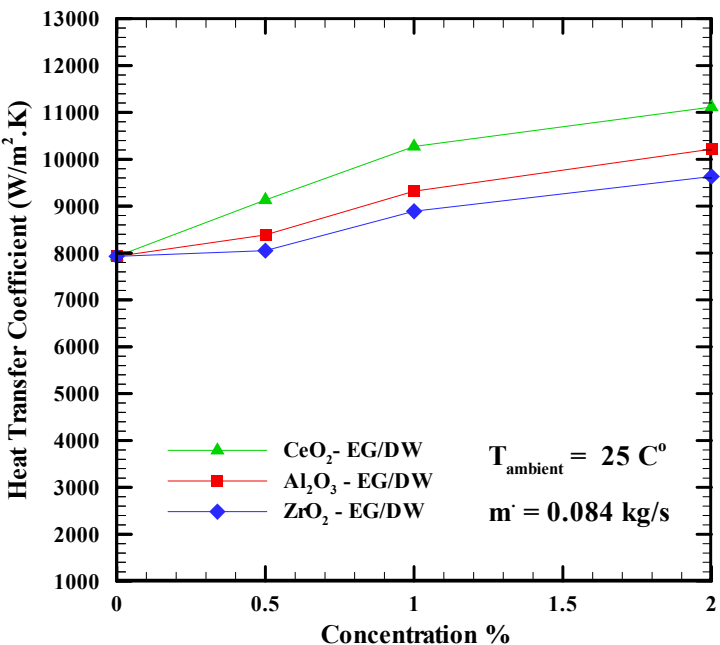

(d)

Figure 6. Heat transfer coefficient versus nanoparticles concentrations at different mass flow rates for nanofluids (a) $\mathrm{CeO}_{2}$-EG/DW, (b) $\mathrm{Al}_{2} \mathrm{O}_{3}$-EG/DW, (c) $\mathrm{ZrO}_{2}$-EG/DW, (d) different nanofluids.

As the convection heat transfer coefficient is an increasing function of the thermal conductivity, Prandtl and Reynolds numbers (h ( $\lambda, \operatorname{Pr}, \operatorname{Re}))$, one can observe that at any flow rate, with the increase 
in concentration, Pr and $\lambda$ increase more than Re decreases due to the increase in viscosity, leading to an increase in the heat transfer coefficient. When the flow rate increases too, the enhancement of the heat transfer coefficient is more prominent.

Figure 7 shows the effect of the variation of the ambient temperature on the heat transfer coefficient when $\mathrm{Al}_{2} \mathrm{O}_{3}-\mathrm{EG} / \mathrm{DW}, \mathrm{CeO}_{2}-\mathrm{EG} / \mathrm{DW}$ nanofluids with a $2 \%$ concentration and a mass flow rate of $0.085 \mathrm{~kg} / \mathrm{s}$ are used. It can be clearly seen for all nanofluids that increasing the ambient temperature leads to a decrease in the heat transfer coefficient. This is because the heat flux increases but the temperature difference between the cooling fluid and the heat sink base temperature increases more and for a specified constant heat transfer surface these corroborated effects lead to a decrease in the heat transfer coefficient (Equation (2)).

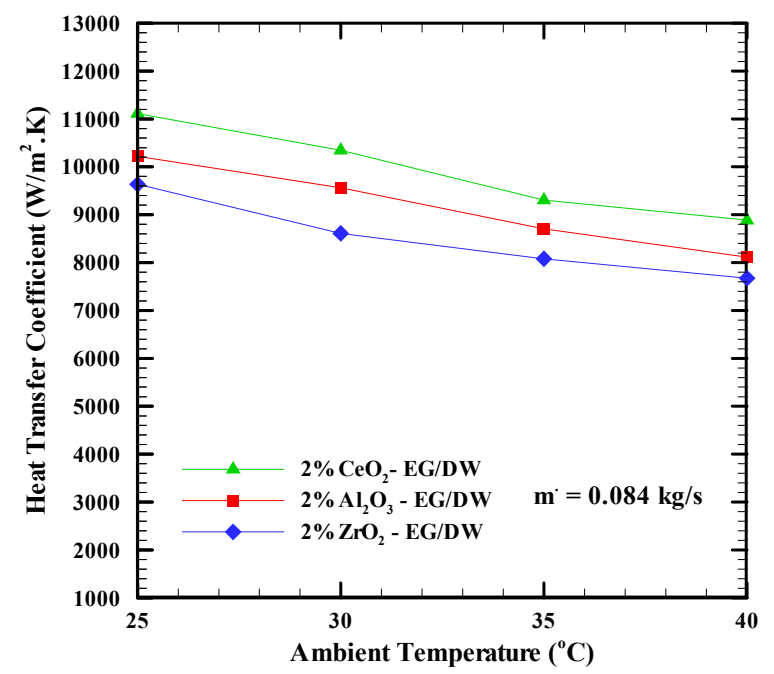

Figure 7. Heat transfer coefficient versus ambient temperature at for different nanofluids.

\subsection{Pressure Drop}

To ensure the benefit of nanofluids in the cooling process, the pressure drop must be investigated, since nanoparticles have been added to the base fluid. The pressure drop occurs when the working fluid passes through the water block and then to the narrow microchannels. Based on the Aqua software, Figure $8 \mathrm{a}-\mathrm{d}$ show the pressure drop of the base fluid and nanofluids $\left(\mathrm{CeO}_{2}-\mathrm{EG} / \mathrm{DW}, \mathrm{Al}_{2} \mathrm{O}_{3}-\mathrm{EG} / \mathrm{DW}\right.$, $\mathrm{ZrO}_{2}-\mathrm{EG} / \mathrm{DW}$ ) for concentrations varying from $0 \%$ to $2 \%$ and mass flow rates varying from $0.028 \mathrm{~kg} / \mathrm{s}$ to $0.084 \mathrm{~kg} / \mathrm{s}$. Generally, from all the figures, it can be demonstrated that the pressure drops in the water block increases when the mass flow and nanoparticle concentration of the nanofluids increase. This phenomenon happens because adding nanoparticles to the base fluid increase the density and cinematic viscosity of the fluid which leads to an increase in the pressure drop; with the increase in the mass flow rate, and consequently of the fluid velocity $(\mathrm{w})$, the pressure drop grows more $(\Delta P(w, \mu))$.

However, Figure $8 \mathrm{~d}$ shows that when the concentration increases from $0 \%$ to $2 \%$ for all nanofluids, the pressure drop shows a slight increase. $\mathrm{Al}_{2} \mathrm{O}_{3}$-EG/DW shows the lowest pressure drop followed by $\mathrm{ZrO}_{2}-\mathrm{EG} / \mathrm{DW}$ and $\mathrm{CeO}_{2}-\mathrm{EG} / \mathrm{DW}$. This is due since $\mathrm{Al}_{2} \mathrm{O}_{3}-\mathrm{EG} / \mathrm{DW}$ has a lower viscosity than the other nanofluids. The $\mathrm{CeO}_{2}$ and $\mathrm{ZrO}_{2}$ nanofluids show very close results at a concentration of $0.5 \%$, but the difference increases when the concentration increases to $2 \%$. 


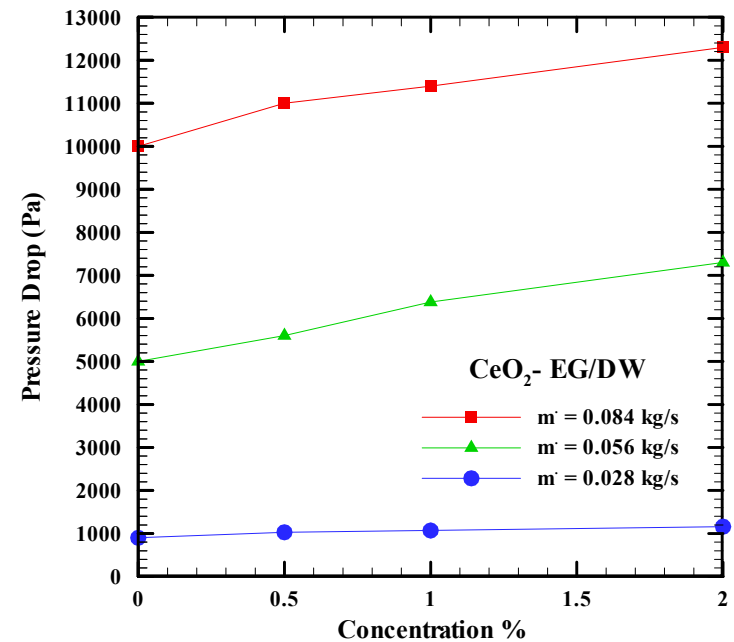

(a)

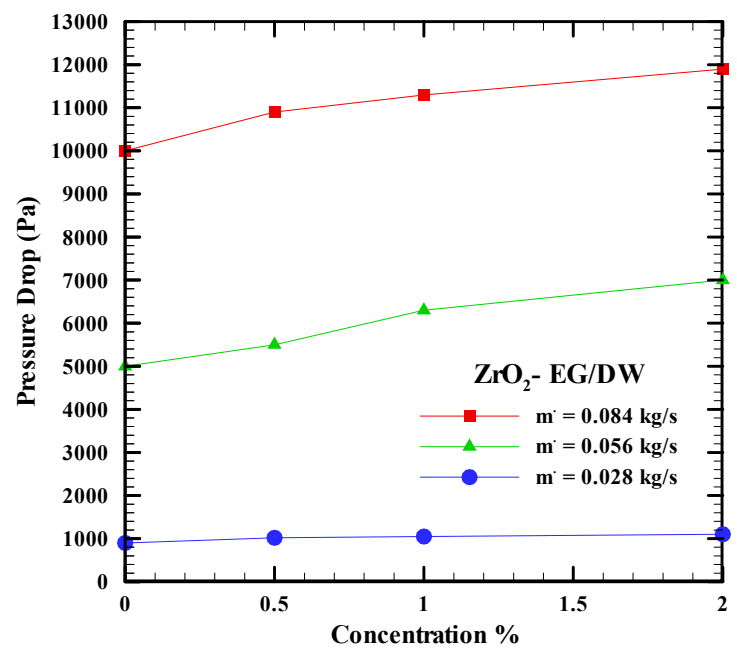

(c)

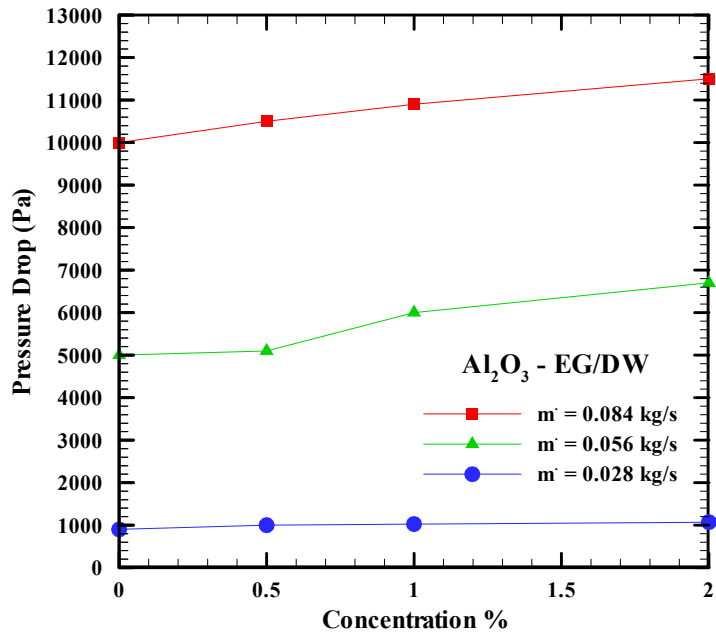

(b)

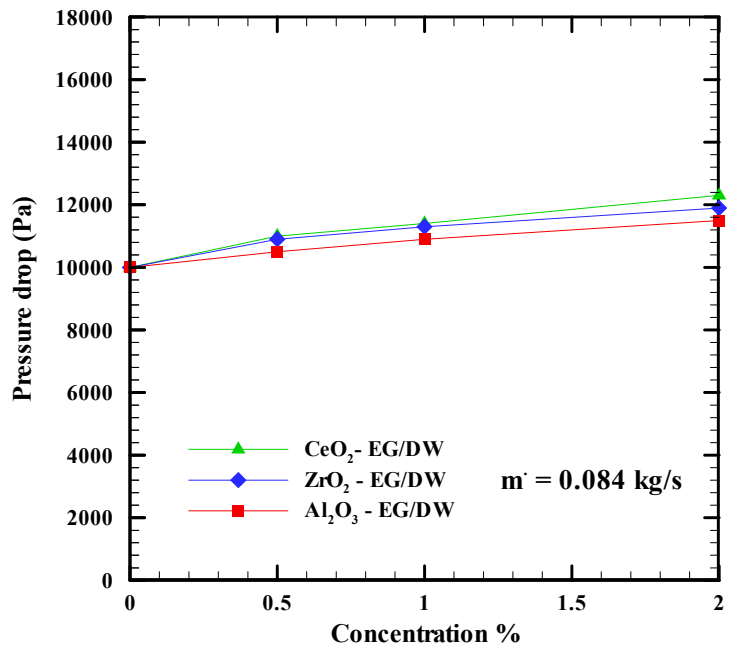

(d)

Figure 8. Pressure drop versus nanoparticles concentrations at different mass flow rates for nanofluids (a) $\mathrm{CeO}_{2}$-EG/DW, (b) $\mathrm{Al}_{2} \mathrm{O}_{3}$-EG/DW, (c) $\mathrm{ZrO}_{2}-\mathrm{EG} / \mathrm{DW}$, (d) different nanofluids.

\subsection{Pumping Power}

Using nanofluids in computer applications as an effective heat transfer working fluid should enhance the heat transfer characteristics without much increase in pumping power. When the working fluid passes over the micro heat sink channels, a pressure drop occurs. The system requires more pumping power to overcome this pressure drop. Figure $9 \mathrm{a}-\mathrm{d}$ show the pumping power versus nanoparticle concentrations of the nanofluid at different mass flows, such as $0.028 \mathrm{~kg} / \mathrm{s}, 0.056 \mathrm{~kg} / \mathrm{s}$, and $0.084 \mathrm{~kg} / \mathrm{s}$. It was shown that adding nanoparticles to the base fluid causes a slight increase in the pumping power, that is balanced by the better thermal performance of the nanofluid compared to the base fluid. Nonetheless, $\mathrm{Al}_{2} \mathrm{O}_{3}$-EG/DW shows the lowest pumping power, while $\mathrm{CeO}_{2}$-EG/DW and $\mathrm{ZrO}_{2}-\mathrm{EG} / \mathrm{DW}$ show very close results to each other. The pumping power follows the trend of the pressure drop, which is amplified by the measure of the fluid velocity (Equation (6)). 


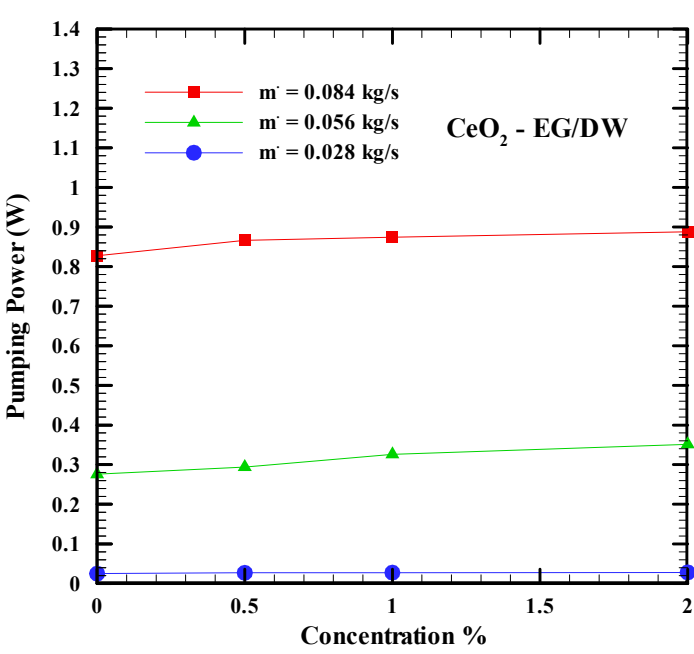

(a)

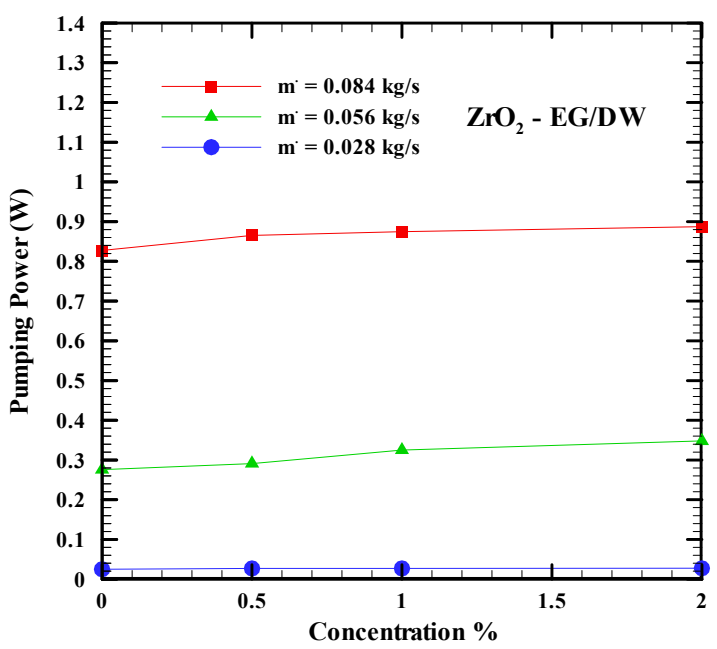

(c)

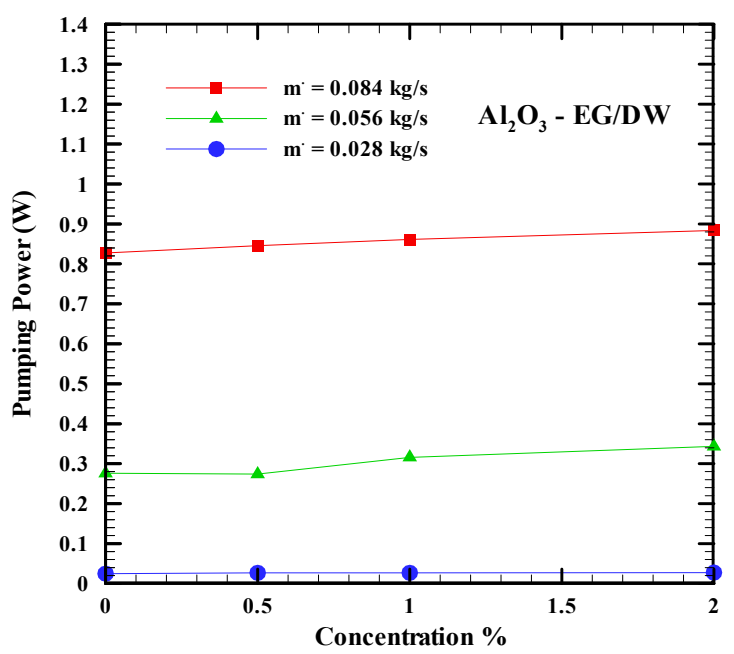

(b)

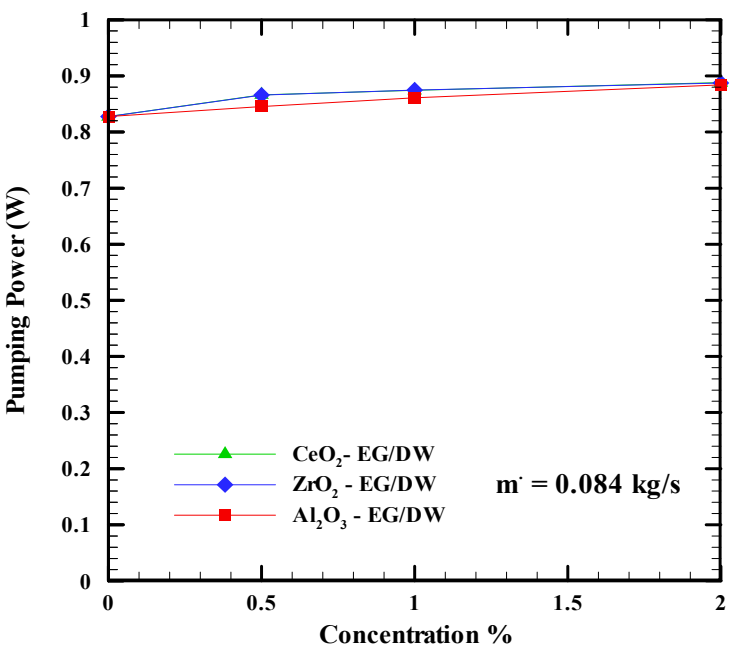

(d)

Figure 9. Pumping power versus nanoparticles concentrations at different mass flow rates for nanofluids (a) $\mathrm{CeO}_{2}$-EG/DW, (b) $\mathrm{Al}_{2} \mathrm{O}_{3}$-EG/DW, (c) $\mathrm{ZrO}_{2}$-EG/DW, (d) different nanofluids.

\section{Conclusions}

In this research, the effects of using different types of nanofluids in computer cooling systems have been experimentally investigated. Three $\mathrm{CeO}_{2}, \mathrm{Al}_{2} \mathrm{O}_{3}$, and $\mathrm{ZrO}_{2}$ nanoparticles were used suspended with $20 \%$ ethylene glycol and $80 \%$ distilled water. The setup and the procedure of the experiment were described in detail. Parameters, such as CPU temperature, ambient temperature, heat transfer coefficient of the base fluid and nanofluids in MCHS, the pressure drop of base fluids and nanofluids in MCHS, and pumping power of the MCHS, have been experimentally investigated. The results point out the following:

- Increasing the concentration of the nanoparticles from $0.5 \%$ to $2 \%$ and increasing the mass flow rate causes a decrease in the base temperature of the heat sink more than the base fluid. The $\mathrm{CeO}_{2}$ nanofluid at a $2 \%$ concentration reduces the temperature with an $8.3 \%$ since the $\mathrm{CeO}_{2}$ nanofluid has the highest thermal conductivity and viscosity. At the same concentration, the $\mathrm{Al}_{2} \mathrm{O}_{3}$ and $\mathrm{ZrO}_{2}$ nanofluids show $6.1 \%$ and $4.2 \%$ temperature decrease, respectively, compared with the base fluid EG/DW (20:80). Moreover, increasing the ambient temperature from $25^{\circ} \mathrm{C}$ to $40{ }^{\circ} \mathrm{C}$ led to an increase of the heat sink base temperature. 
- Adding nanoparticles to the base fluid and increasing the mass flow rate leads to an increase in the heat transfer coefficient much more than the base fluid. The $\mathrm{CeO}_{2}$ nanofluid shows the highest heat transfer coefficient with a $29 \%$ enhancement, while the $\mathrm{Al}_{2} \mathrm{O}_{3}$ nanofluid shows a $22 \%$ enhancement. The $\mathrm{ZrO}_{2}$ showed a $17 \%$ enhancement. Furthermore, increasing the ambient temperature from $25{ }^{\circ} \mathrm{C}$ to $40{ }^{\circ} \mathrm{C}$ led to a decrease in the heat transfer coefficient.

- The pressure drops and pumping power increase when the mass flow rate and concentration of the nanofluid increases. The $\mathrm{Al}_{2} \mathrm{O}_{3}$-EG/DW shows the lowest value followed by $\mathrm{ZrO}_{2}$-EG/DW and $\mathrm{CeO}_{2}-\mathrm{EG} / \mathrm{DW}$. However, a slight increase of pumping power and pressure drop can be balanced by considering the high improvement of the nanofluid in computer cooling performance compared to the base fluid.

- The novelty of the study consists in providing information about the comparative behavior of $\mathrm{CeO}_{2}, \mathrm{Al}_{2} \mathrm{O}_{3}$ and $\mathrm{ZrO}_{2}$ nanoparticles suspended in EG/DW (20:80) when used as cooling fluids in computer cooling systems. Graphs are provided with the variation of the convective heat transfer coefficient, heat sink base temperature, pressure drop and pumping power, against the nanoparticles concentration in nanofluids and the mass flow rate of the cooling fluid.

- From an academic point of view, the work establishes a procedure for the preparation and characterization of nanofluids. An experimental setup was created to investigate the heat transfer performances of a computer cooling system with nanofluids as the cooling fluid. Of academic interest is the data processing developed in the work.

Author Contributions: Conceptualization, A.A., L.M., H.P., V.A., A.D.; methodology, A.A., A.D.; software, A.A.; formal analysis, A.A., A.D., M.-F.S.; investigation, A.A., H.P., V.A., A.D.; resources, A.A., L.M., A.D.; data curation, A.A., A.D.; writing—original draft preparation, A.A., H.P., A.D.; writing-review and editing, A.A., H.P., A.D., M.-F.S.; visualization, A.A., A.D.; supervision, A.D.; project administration, H.P., V.A., M.-F.S., A.D.; funding acquisition, M.-F.S.

Funding: This research was funded by University POLITEHNICA of Bucharest.

Acknowledgments: This work was supported by the University POLITEHNICA of Bucharest (UPB). The authors would like to thank UPB for the sponsorship.

Conflicts of Interest: The authors declare no conflict of interest.

\section{References}

1. Tuckerman, D.B.; Pease, R.F. High performance heat sinking for VLSI. IEEE Electron Device Lett. 1981, 2, 126-129. [CrossRef]

2. Lee, J.; Mudawar, I. Assessment of the effectiveness of nanofluids for single-phase and two-phase heat transfer in micro-channels. Int. J. Heat Mass Transf. 2007, 50, 452-463. [CrossRef]

3. Khonsue, O. Experimental on the liquid cooling system with thermoelectric for personal computer. Heat Mass Transf. 2012, 48, 1767-1771. [CrossRef]

4. Tran, N.; Zhang, C.; Dang, T.; Teng, J. Numerical and experimental studies on pressure drop and performance index of an aluminum microchannel heat sink. In Proceedings of the 2012 International Symposium on Computer, Consumer and Control, Taichung, Taiwan, 4-6 June 2012; pp. 252-257.

5. Ma, D.D.; Xia, G.D.; Wang, J.; Yang, Y.C.; Jia, Y.T.; Zong, L.X. An experimental study on hydrothermal performance of microchannel heat sinks with 4-ports and offset zigzag channels. Energy Convers. Manag. 2017, 152, 157-165. [CrossRef]

6. Choi, S.U.; Eastman, J.A. Enhancing thermal conductivity of fluids with nanoparticles. In ASME International Mechanical Engineering Congress E Exposition; American Society of Mechanical Engineers: Fairfield, CT, USA, 1995.

7. Raja, M.; Vijayana, R.; Dineshkuma, P.; Venkatesan, M. Review on nanofluids characterization, heat transfer characteristics and applications. Renew. Sustain. Energy Rev. 2016, 64, 163-173. [CrossRef]

8. Lomascolo, M.; Colangelo, G.; Milanese, M.; Risi, A. Review of heat transfer in nanofluids: Conductive, convective and radiative experimental results. Renew. Sustain. Energy Rev. 2015, 43, 1182-1198. [CrossRef] 
9. Nandhakumar, R.; Senthilkumar, D. An experimental investigation on thermal performance of nanofluids in a minichannel heat sink. J. Adv. Chem. 2016, 12, 5152-5162.

10. Jeong, J.; Li, C.; Kwon, Y.; Lee, J.; Kim, S.H.; Yun, R. Particle shape effect on the viscosity and thermal conductivity of $\mathrm{ZnO}$ nanofluids. Int. J. Refrig. 2013, 36, 2233-2241. [CrossRef]

11. Lee, S.; Choi, S.U.; Li, S.; Eastman, J. Measuring thermal conductivity of fluids containing oxide nanoparticles. J. Heat Transf. 1999, 121, 280-289. [CrossRef]

12. Alawi, O.A.; Sidik, N.A.C.; Xian, H.W.; Kean, T.H.; Kazi, S.N. Thermal conductivity and viscosity models of metallic oxides nanofluids. Int. J. Heat Mass Transf. 2018, 116, 1314-1325. [CrossRef]

13. Namburu, P.K.; Das, D.K.; Tanguturi, K.M.; Vajjha, R.S. Numerical study of turbulent flow and heat transfer characteristics of nanofluids considering variable properties. Int. J. Therm. Sci. 2009, 48, 290-302. [CrossRef]

14. Eastman, J.A.; Choi, S.U.S.; Li, S.; Yu, W.; Thompson, L.J. Anomalously increased Effective thermal conductivities of ethylene glycol-based nanofluids containing copper nanoparticles. Appl. Phys. Lett. 2001, 78, 718-720. [CrossRef]

15. Esfe, M.H.; Wongwises, S.; Naderi, A.; Asadi, A.; Safaei, M.R.; Rostamian, H.; Dahari, M.; Karimipour, A. Thermal conductivity of $\mathrm{Cu} / \mathrm{TiO}_{2}-$ Water/EG hybrid nanofluid: Experimental data and modeling using artificial neural network and correlation. Int. Commun. Heat Mass Transf. 2015, 66, 100-104. [CrossRef]

16. Hamid, K.A.; Azmi, W.H.; Nabil, M.F.; Mamat, R. Experimental investigation of nanoparticle mixture ratios on $\mathrm{TiO}_{2}-\mathrm{SiO}_{2}$ nanofluids heat transfer performance under turbulent flow. Int. Commun. Heat Mass Transf. 2018, 118, 617-627. [CrossRef]

17. Siddiqui, F.R.; Tso, C.Y.; Chan, K.C.; Fu, S.C.; Chao, C.Y.H. On trade-off for dispersion stability and thermal transport of $\mathrm{Cu}-\mathrm{Al}_{2} \mathrm{O}_{3}$ hybrid nanofluid for various mixing ratios. Int. Commun. Heat Mass Transf. 2019, 132, 1200-1216. [CrossRef]

18. Chopkar, M.; Kumar, S.; Bhandari, D.; Das, P.K.; Manna, I. Development and characterization of $\mathrm{Al}_{2} \mathrm{Cu}$ and $\mathrm{Ag}_{2} \mathrm{Al}$ nanoparticle dispersed water and ethylene glycol based nanofluid. Mater. Sci. Eng. B 2007, 139, 141-148. [CrossRef]

19. Baby, T.T.; Ramaprabhu, S. Synthesis and nanofluid application of silver nanoparticles decorated grapheme. J. Mater. Chem. 2011, 21, 9702-9709. [CrossRef]

20. Chen, L.F.; Cheng, M.; Yang, D.J.; Yang, L. Enhanced thermal conductivity of nanofluid by synergistic effect of multi-walled carbon nanotubes and $\mathrm{Fe}_{2} \mathrm{O}_{3}$ nanoparticles. Appl. Mech. Mater. 2014, 548, 118-123.

21. Yiamsawasd, T.; Dalkilic, A.S.; Wongwisesa, S. Measurement of the thermal conductivity of Titania and alumina nanofluids. Thermochim. Acta 2012, 545, 48-56. [CrossRef]

22. Kumaresan, V.; Velraj, R. Experimental investigation of the thermo-physical properties of water-ethylene glycol mixture based CNT nanofluids. Thermochim. Acta 2012, 545, 180-186. [CrossRef]

23. Yu, W.; Xie, H.; Li, Y.; Chen, L.; Wang, Q. Experimental investigation on the heat transfer properties of $\mathrm{Al}_{2} \mathrm{O}_{3}$ nanofluids using the mixture of ethylene glycol and water as base fluid. Powder Technol. 2012, 230, 14-19. [CrossRef]

24. Hamid, K.A.; Azmi, W.H.; Mamat, R.; Sharma, K.V. Experimental investigation on heat transfer performance of $\mathrm{TiO}_{2}$ nanofluids in water-ethylene glycol mixture. Int. Commun. Heat Mass Transf. 2016, 73, 16-24. [CrossRef]

25. Namburu, P.K.; Kulkarni, D.P.; Misra, D.; Das, D.K. Viscosity of copper oxide nanoparticles dispersed in ethylene glycol and water mixture. Exp. Therm. Fluid Sci. 2007, 32, 67-71. [CrossRef]

26. Vajjha, R.S.; Das, D.K. Experimental determination of thermal conductivity of three nanofluids and development of new correlations. Int. Commun. Heat Mass Transf. 2009, 52, 4675-4682. [CrossRef]

27. Reddy, M.C.S.; Rao, V.V. Experimental studies on thermal conductivity of blends of ethylene glycol-water-based $\mathrm{TiO}_{2}$ nanofluids. Int. Commun. Heat Mass Transf. 2013, 46, 31-36. [CrossRef]

28. Li, X.; Zou, C. Thermo-physical properties of water and ethylene glycol mixture based SiC nanofluids: An experimental investigation. Int. Commun. Heat Mass Transf. 2016, 101, 412-417. [CrossRef]

29. Sundar, L.S.; Ramana, E.V.; Singh, M.K.; Sousa, A.C.M. Thermal conductivity and viscosity of stabilized ethylene glycol and water mixture $\mathrm{Al}_{2} \mathrm{O}_{3}$ nanofluids for heat transfer applications: An expermintal study. Int. Commun. Heat Mass Transf. 2014, 56, 86-95. [CrossRef]

30. Sundar, L.S.; Singh, M.K.; Sousa, A.C.M. Thermal conductivity of ethylene glycol and water mixture based $\mathrm{Fe}_{3} \mathrm{O}_{4}$ nanofluid. Int. Commun. Heat Mass Transf. 2013, 49, 17-24. [CrossRef] 
31. Ahmed, H.E.; Mohammed, H.A.; Yusoff, M.Z. An overview on heat transfer augmentation using vortex generators and nanofluids: Approaches and applications. Renew. Sustain. Energy Rev. 2012, 16, 5951-5993. [CrossRef]

32. Xuan, Y.; Roetzel, W. Concepts for heat transfer correlation of nanofluids. Int. Commun. Heat Mass Transf. 2000, 43, 3701-3707. [CrossRef]

33. Lazarus, G.; Raja, B.; Mohan, L.D.; Wongwises, S. Enhancement of heat transfer using nanofluids-An overview. Renew. Sustain. Energy Rev. 2010, 14, 629-641.

34. Keblinski, P.; Eastman, J.A.; Cahill, D.G. Nanofluids for thermal transport. Mater. Today 2005, 8, 36-44. [CrossRef]

35. Nguyen, C.T.; Roy, G.; Galanis, N.; Suiro, S. Heat Transfer Enhancement by using $\mathrm{Al}_{2} \mathrm{O}_{3}$-Water Nanofluid in a Liquid Cooling System for Microprocessors. In Proceedings of the 4th WSEAS International Conference on Heat Transfer, Thermal Engineering and Environment, Venice, Italy, 20-22 November 2006; pp. 103-108.

36. Chein, R.; Chuang, J. Experimental microchannel heat sink performance studies using nanofluids. Int. J. Therm. Sci. 2007, 46, 57-66. [CrossRef]

37. Ho, C.J.; Wei, L.C.; Li, Z.W. An experimental investigation of forced convective cooling performance of a microchannel heat sink with $\mathrm{Al}_{2} \mathrm{O}_{3}$ /water nanofluid. Appl. Therm. Eng. 2010, 30, 96-103. [CrossRef]

38. Tiwari, A.K.; Ghosh, P.; Sarkar, J. Performance comparison of the plate heat exchanger using different nanofluids. Exp. Therm. Fluid Sci. 2013, 49, 141-151. [CrossRef]

39. Haghighi, E.B.; Anwar, Z.; Lumbreras, I.; Mirmohammadi, S.A.; Behi, M.; Khodabandeh, R.; Palm, B. Screening single phase laminar convective heat transfer of nanofluids in a micro-tube. J. Phys. Conf. Ser. 2012, 395, 012-036. [CrossRef]

40. Rimbault, B.; Nguyen, C.T.; Galanis, N. Experimental investigation of CuO-water nanofluid flow and heat transfer inside a microchannel heat sink. Int. J. Therm. Sci. 2014, 84, 275-292. [CrossRef]

41. Nazari, M.; Karami, M.; Ashouri, M. Comparing the thermal performance water, Ethylene Glycol, Alumina and CNT Nanofluids in CPU Cooling: Experimental study. Exp. Therm. Fluid Sci. 2014, 57, 371-377. [CrossRef]

42. Sivakumar, A.; Alagumurthi, N.; Senthilvelan, T. Effect of serpentine grooves on heat transfer characteristics of microchannel heat sink with different nanofluids. Heat Transf. Asian Res. 2015, 46, 201-217. [CrossRef]

43. Singh, M.; Kumar, R. Design and Experimental Analysis of Rectangular Wavy Micro Channel Heat sink. Int. J. Innov. Res. Adv. Eng. 2016, 3, 23492763.

44. Arslan, A.; Halelfadl, S.; Mare, T.; Estelle, P.; Doner, N.; Mohd-Ghazali, N. Experimental investigation of a microchannel heat sink performance using aqueous carbon nanotubes based nanofluid. In Proceedings of the 5th International Conference on Applied Energy, Beijing, China, 8-11 October 2016.

45. Thansekhar, M.R.; Anbumeenakshi, C. Experimental investigation of thermal performance of microchannel heat sink with nanofluids $\mathrm{Al}_{2} \mathrm{O}_{3} /$ Water and $\mathrm{SiO}_{2} /$ Water. Exp. Tech. 2017, 41, 399-406. [CrossRef]

46. Manay, E.; Sahin, B. Heat transfer and pressure drop of nanofluids in a microchannel heat sink. Heat Transf. Eng. 2017, 38, 510-522. [CrossRef]

47. Esfe, M.H.; Afrand, M.; Karimipour, A.; Yanb, W.M.; Sina, N. An experimental study on thermal conductivity of $\mathrm{MgO}$ nanoparticles suspended in a binary mixture of water and ethylene glycol. Int. Commun. Heat Mass Transf. 2015, 67, 173-175. [CrossRef]

48. Usri, N.A.; Azmi, W.H.; Mamat, R.; Hamid, K.A.; Najafi, G. Thermal conductivity enhancement of $\mathrm{Al}_{2} \mathrm{O}_{3}$ nanofluid in ethylene glycol and water mixture. Energy Procedia 2015, 79, 397-402. [CrossRef]

49. DOW. Engineering and Operating Guide for DOWTHERM SR-1 and DOWTHERM 4000 Inhibited Ethylene Glycol-based Heat Transfer Fluids. North Amerca-USA and Canada. 2008, pp. 1-44. Available online: https://www.dow.com/en-us (accessed on 15 April 2019).

50. Alfaryjat, A.A.; Mohammed, H.A.; Adam, N.M.; Stanciu, D.; Dobrovicescua, A. Numerical investigation of heat transfer enhancement using various nanofluids in hexagonal microchannel heat sink. Therm. Sci. Eng. Prog. 2018, 5, 252-262. [CrossRef]

51. Available online: www.asus.com (accessed on 15 April 2019).

52. Intel. Intel ${ }^{\circledR}$ Celeron $^{\circledR}$ Dual-Core Processor, Thermal and Mechanical Design Guidelines; Intel: Santa Clara, CA, USA, 2017. 
53. Rafati, M.; Hamidi, A.A.; Niaser, M.S. Application of nanofluids in computer cooling systems (heat transfer performance of nanofluids). Appl. Therm. Eng. 2012, 45, 9-14. [CrossRef]

54. Wu, X.; Wu, H.; Cheng, P. Pressure drop and heat transfer of $\mathrm{Al}_{2} \mathrm{O}_{3}-\mathrm{H}_{2} \mathrm{O}$ nanofluids through silicon microchannels. J. Micromech. Microeng. 2009, 19, 105020. [CrossRef]

(C) 2019 by the authors. Licensee MDPI, Basel, Switzerland. This article is an open access article distributed under the terms and conditions of the Creative Commons Attribution (CC BY) license (http://creativecommons.org/licenses/by/4.0/). 